University of Nebraska - Lincoln

DigitalCommons@University of Nebraska - Lincoln

2002

\title{
Biomineralization of Poorly Crystalline Fe(III) Oxides by Dissimilatory Metal Reducing Bacteria (DMRB)
}

John M. Zachara

Pacific Northwest National Laboratory, john.zachara@pnl.gov

Ravi K. Kukkadapu

Pacific Northwest National Laboratory, ravi.kukkadapu@pnl.gov

James K. Fredrickson

Pacific Northwest National Laboratory, jim.fredrickson@pnl.gov

Yuri A. Gorby

Pacific Northwest National Laboratory

Steven C. Smith

Pacific Northwest National Laboratory

Follow this and additional works at: https://digitalcommons.unl.edu/usdoepub

Part of the Bioresource and Agricultural Engineering Commons

Zachara, John M.; Kukkadapu, Ravi K.; Fredrickson, James K.; Gorby, Yuri A.; and Smith, Steven C., "Biomineralization of Poorly Crystalline Fe(III) Oxides by Dissimilatory Metal Reducing Bacteria (DMRB)" (2002). US Department of Energy Publications. 166.

https://digitalcommons.unl.edu/usdoepub/166

This Article is brought to you for free and open access by the U.S. Department of Energy at DigitalCommons@University of Nebraska - Lincoln. It has been accepted for inclusion in US Department of Energy Publications by an authorized administrator of DigitalCommons@University of Nebraska - Lincoln. 


\title{
Biomineralization of Poorly Crystalline Fe(III) Oxides by Dissimilatory Metal Reducing Bacteria (DMRB)
}

\author{
JOHN M. ZACHARA \\ RAVI K. KUKKADAPU \\ JAMES K. FREDRICKSON \\ YURI A. GORBY \\ STEVEN C. SMITH \\ Pacific Northwest National Laboratory \\ Richland, Washington, USA
}

\begin{abstract}
Dissimilatory metal reducing bacteria (DMRB) catalyze the reduction of $\mathrm{Fe}(I I I)$ to $\mathrm{Fe}(I I)$ in anoxic soils, sediments, and groundwater. Two-line ferrihydrite is a bioavailable $\mathrm{Fe}(\mathrm{III})$ oxide form that is exploited by DMRB as a terminal electron acceptor. A wide variety of biomineralization products result from the interaction of DMRB with 2-line ferrihydrite. Here we describe the state of knowledge on the biotransformation of synthetic 2-line ferrihydrite by laboratory cultures of DMRB using select published data and new experimental results. A facultative DMRB is emphasized (Shewanella putrefaciens) upon which most of this work has been performed. Key factors controlling the identity of the secondary mineral suite are evaluated including medium composition, electron donor and acceptor concentrations, ferrihydrite aging/recrystallization status, sorbed ions, and co-associated crystalline Fe(III) oxides. It is shown that crystalline ferric (goethite, hematite, lepidocrocite), ferrous (siderite, vivianite), and mixed valence (magnetite, green rust) iron solids are formed in anoxic, circumneutral DMRB incubations. Some products are well rationalized based on thermodynamic considerations, but others appear to result from kinetic pathways driven by ions that inhibit interfacial electron transfer or the precipitation of select phases. The primary factor controlling the nature of the secondary mineral suite appears to be the Fe(II) supply rate and magnitude, and its surface reaction with the residual oxide and other sorbed ions. The common observation of end-product mineral mixtures that are not at global equilibrium indicates that microenvironments surrounding respiring DMRB cells or the reaction-path trajectory (over Eh-pH space) may influence the identity of the final biomineralization suite.
\end{abstract}

Keywords biogenic Fe(II), biomineralization, crystalline Fe(III) oxides, dissimilatory iron reduction, ferrihydrite, ferrous iron minerals, Mössbauer spectroscopy

Received 19 December 2000; accepted 16 November 2001.

Research was supported by the Office of Basic Energy Sciences (OBES)—Geosciences Program, U.S. Department of Energy (DOE). Pacific Northwest National Laboratory is operated for the DOE by Battelle Memorial Institute under Contract DE-AC06-76RLO 1830.

This work was supported by the U.S. Department of Energy, Office of Basic Energy Sciences, Engineering and Geosciences Division. The research was performed at the W.R. Wiley Environmental Molecular Sciences Laboratory, a national scientific user facility sponsored by the U.S. Department of Energy's Office of Biological and Environmental Research located at Pacific Northwest National Laboratory. It is operated for the U.S. Department of Energy by Battelle Memorial Institute under Contract DE-AC06-76RL01830 .

Address correspondence to John M. Zachara, Pacific Northwest National Laboratory, P.O. Box 999, Mail Stop K8-96, Richland, WA 99352, USA. E-mail: john.zachara@ pnl.gov 
Poorly crystalline Fe(III) oxides are common secondary weathering products found in soils, unsaturated and saturated subsurface materials, aquatic sediments, and geologic materials. One common form of poorly crystalline Fe(III) oxide is ferrihydrite (Childs 1992), the subject of this paper. Ferrihydrites are typically finely divided, exhibit high surface area, and often exist as particle coatings on rock fragments that have served as Fe-sources in soils and subsurface sediments, as suspended material in groundwater, and as water-column precipitates near oxic-anoxic interfaces in natural waters (Whittmore and Langmuir 1975; Schwertmann et al. 1982; Fortin et al. 1993). They precipitate readily, form abiotically or biotically by Fe(II) oxidation and Fe(III) hydrolysis (Cornell and Schwertmann 1996), and are often associated with biologic materials and organic matter in natural waters (Fortin et al. 1993; Perret et al. 2000). Ferrihydrite functions as a sorbent and repository for both contaminants and nutrients, acts as redox and proton buffering phase in soil and sediment porewaters and groundwaters, and is a precursor for the formation of the common crystalline $\mathrm{Fe}(\mathrm{III})$ oxides (goethite, hematite).

Ferrihydrite is especially important as an electron acceptor in soils, sediments, and aquifers because it is more bioavailable to dissimilatory metal reducing bacteria (DMRB) then crystalline ones (Lovley et al. 1991; Lovley and Phillips 1986; Phillips et al. 1993). The bioavailable Fe(III) fraction in sediments qualitatively correlates with ammonium oxalate extractable $\mathrm{Fe}(\mathrm{III})\left(\mathrm{Fe}_{\mathrm{o}}\right)$ (Lovley and Phillips 1987). Mineralogic analyses (X-ray diffraction, Mössbauer spectroscopy) indicate that $\mathrm{Fe}_{0}$, in turn, approximates the ferrihydrite content of a soil or sediment (Campbell and Schwertmann 1984, 1985; Cornell and Schwertmann 1996). Both specimen and natural crystalline Fe(III) oxides are bioreducible by DMRB to a certain degree (Lovley et al. 1991; Roden and Zachara 1996; Zachara et al. 1998; Kukkadapu et al. 2001), and their extent of reduction appears related to surface area (Roden and Zachara 1996), thermodynamic factors (Postma and Jakobsen 1996; Liu et al. 2001a), degree of structural disorder (Zachara et al. 1998), and extent of surface passivation by sorbed Fe(II) (Roden and Zachara 1996). In batch suspensions with DMRB, ferrihydrite is often fully reduced or transformed to secondary ferrous containing mineral solids (e.g., Fredrickson et al. 1998; Fredrickson et al. 2001) whereas goethite and hematite are only partially reduced (Zachara et al. 1998). Water advection enhances the extent of crystalline Fe(III) oxide reduction (Roden and Urrutia 1999; Roden et al. 2000), perhaps through relaxation of thermodynamic constraints or surface passivation. Results to date indicate that poorly crystalline $\mathrm{Fe}(\mathrm{III})$ oxides support greater amounts of electron donor oxidation by DMRB than crystalline ones, all other factors held constant.

DMRB solubilize poorly crystalline $\mathrm{Fe}(\mathrm{III})$ oxides as $\mathrm{Fe}_{(\mathrm{aq})}^{2+}$ or transform them to ferrous containing solid phases during bioreduction. Reported secondary products of ferrihydrite bioreduction include: siderite $\left(\mathrm{FeCO}_{3}\right.$; Mortimer and Coleman 1997; Fredrickson et al. 1998), magnetite $\left(\mathrm{Fe}_{3} \mathrm{O}_{4}\right.$; Lovley 1991; Mortimer and Coleman 1997; Mortimer et al. 1997), vivianite $\left[\mathrm{Fe}_{3}\left(\mathrm{PO}_{4}\right)_{2} \cdot 8 \mathrm{H}_{2} \mathrm{O}\right]$ (Fredrickson et al. 1998), and green rust $\left\{\left[\mathrm{Fe}_{(6-\mathrm{x})}^{\mathrm{II}}\right.\right.$ $\left.\left.\mathrm{Fe}_{(\mathrm{x})}^{\mathrm{III}}(\mathrm{OH})_{12}\right]^{\mathrm{x}+}\left[\left(\mathrm{A}^{2-}\right)_{\mathrm{x} / 2} \cdot y \mathrm{H}_{2} \mathrm{O}\right]^{\mathrm{x}-}\right\}$ (Fredrickson et al. 1998; Parmar et al. 2001). The biomineralization products are important in that they influence the overall thermodynamics of the bioreduction reaction, and consequently its extent (Zachara et al. 1998). Also, biomineralization is integral to the rate and kinetics of the overall bioreduction process. The secondary products may assist bioreduction by removing or lowering the thermodynamic activity of reaction byproducts [e.g., $\mathrm{Fe}(\mathrm{II})]$, or may retard bioreduction by coating or passivating the residual Fe(III) oxide or DMRB surface (Liu et al. 2001a, 2001b). Biomineralization products may also sequester trace elements associated with the original oxide by coprecipitation or surface complexation (Zachara et al. 2001).

Here we address the biotransformation of ferrihydrite by DMRB with emphasis on secondary mineral formation. A synthetic, 2-line ferrihydrite is used as a qualitative surrogate 
of an important component of the bioavailable iron oxide fraction in soils, sediments, and geologic material. This material is used in unreacted state, and after coreaction with a number of anionic and cationic solutes to produce ferrihydrites of greater environmental relevance. We begin with a review on the nature of ferrihydrite, and its thermodynamic relationships to other Fe-solids that represent potential transformation products. Experimental information is then provided on the identity of biomineralization products resulting from the action of DMRB on 2-line ferrihydrite. Chemical and biologic factors are evaluated that appear to control the biomineralization process. It is shown that a complex array of both ferric and ferrous iron phases are formed when DMRB utilize 2-line ferrihydrite as a terminal electron acceptor, and that the primary controlling factor is the respiration-driven biogenic $\mathrm{Fe}$ (II) supply rate. Although many of the products may be well rationalized based on thermodynamic considerations, others appear to result from kinetic pathways with unique biotic signature. The level of scientific understanding is found to be insufficient to allow prediction of the final phase assemblage, and key areas are identified where research is needed.

\section{Background}

\section{The Nature of Ferrihydrite}

As noted in the introduction, acid ammonium oxalate (AAO) extractable $\mathrm{Fe}\left(\mathrm{Fe}_{\mathrm{o}}\right)$ qualitatively correlates with the bioavailable Fe(III) fraction, and the ferrihydrite content of a soil or sediment. Natural Fe(III) oxides span a wide range of crystallinity, structure, size, and solubility. Whereas AAO preferentially dissolves ferrihydrite over goethite and hematite (Schwertmann et al. 1982; Campbell and Schwertmann 1985), the dissolution kinetics of a particular Fe(III) oxide in AAO is strongly dependent on these properties and consequently extraction time is a key variable in controlling the phase specificity and extent of extraction. Wang et al. (1993), for example, observed that ferrihydrite was extracted by AAO within $30 \mathrm{~min}$, while longer extraction times (e.g., 50-180 $\mathrm{min}$ ) dissolved lepidocrocite of progressively increasing size. More crystalline or Si-containing ferrihydrite may require greater than $120 \mathrm{~min}$ of extraction for complete removal (Schwertmann 1973). Magnetite and small particle goethite may also dissolve to certain degree in AAO. Consequently, the AAO technique as typically applied with a 2-h extraction time (Lovley and Phillips 1987) is not a quantitative or uniquely selective extractant of ferrihydrite or any other Fe(III) oxide phase for that matter.

Ferrihydrites exhibit a continuum in structure from amorphous to partly crystalline. The term hydrous ferric oxide (HFO, e.g., Dzombak and Morel 1990) is applied to a material synthesized in the laboratory by rapid hydrolysis of a $\mathrm{Fe}(\mathrm{III})$ salt solution, with approximately 4- to 8-h aging at $\mathrm{pH}$ 7. This material may be amorphous (protoferrihydrite) or exhibit two broad X-ray diffraction (XRD) maxima (2-line ferrihydrite). HFO and 2-line ferrihydrite are often used synonymously (Cornell and Schwertmann 1996). A more crystalline variety (6-line ferrihydrite) is prepared by heat-induced hydrolysis (Cornell and Schwertmann 1991). These 2- and 6-line ferrihydrites represent end members to a continuum that span a range in X-ray diffraction patterns and physical characteristics that result from differences in synthesis conditions. As noted by Childs (1992), the XRD peaks of ferrihydrite are broad and weak and the number of resolvable diffraction lines depends on sample preparation, the diffraction instrument and its operation conditions, and interpretation. The 2- and 6-line ferrihydrites precipitate under different conditions and the 2-line variety apparently does not transform to the 6-line variety with time (Cornell and Schwertmann 1996).

The molecular structure of ferrihydrite has been investigated by various techniques including XRD, Mössbauer spectroscopy, and X-ray scattering/X-ray absorption (Pankhurst 
and Pollard 1992; Stanjek and Weidler 1992; Manceau and Drits 1993), without great consensus (see review by Cornell and Schwertmann 1996). Six-line ferrihydrite is believed to exhibit a defective hematite structure with significant $\mathrm{Fe}(\mathrm{III})$ vacancies and considerable sorbed water (Towe and Bradley 1967; Chukhrov et al. 1973; Russell et al. 1979). Twoline ferrihydrite is more disordered and is thought to consist of coherent domains of four planar $\mathrm{Fe}(\mathrm{O}, \mathrm{OH})_{6}$ groups (Feitknecht et al. 1973). The high degree of disorder and large water content leads to a variable stoichiometric composition for ferrihydrite that has proved difficult to characterize. Stanjek and Weidler (1992), for example, proposed a bulk formula of $\mathrm{Fe}_{1.55} \mathrm{O}_{1.66}(\mathrm{OH})_{1.33}$.

\section{Thermodynamic Stability and Phase Transformations Under Oxidizing Conditions}

Under oxidizing conditions, ferrihydrites are thermodynamically unstable with respect to crystalline $\mathrm{Fe}(\mathrm{III})$ oxides including maghemite $\left(\gamma-\mathrm{Fe}_{2} \mathrm{O}_{3}\right)$, lepidocrocite $(\gamma$-FeOOH$)$, hematite $\left(\propto-\mathrm{Fe}_{2} \mathrm{O}_{3}\right)$, and goethite $(\propto-\mathrm{FeOOH})$ (Figure 1). Ferrihydrite is described in Figure 1 as $\mathrm{Fe}(\mathrm{OH})_{3}$ for ease of computation. Other, more complex stoichiometric formula have been proposed including $\mathrm{Fe}(\mathrm{OH})_{2.35}$ from solubility studies (Fox 1988, 1988a) and $\mathrm{Fe}_{2} \mathrm{O}_{3} \cdot 2 \mathrm{FeOOH} \cdot 2.6 \mathrm{H}_{2} \mathrm{O}$ from infrared spectroscopy (Russell 1979). These different stoichiometric representations of ferrihydrite do not change the fact that this phase is less stable than the crystalline Fe(III) oxides. Factors controlling the rate and extent of ferrihydrite conversion to crystalline $\mathrm{Fe}$ (III) oxides have been extensively studied in the laboratory (see review by Cornell and Schwertmann 1996) and involve $\mathrm{pH}$, foreign inorganic and organic ions, temperature, and others. Both 2- and 6-line ferrihydrites begin crystallization toward goethite (primarily) and hematite in laboratory suspensions at room temperature over periods of weeks to months. Such crystallization is accompanied by changes in internal structure and water content, morpholog y and particle size, surface area, concentrations of undercoordinated surface sites, and thermodynamic properties such as solubility (Schindler et al. 1963). These changes that accompany aging and crystallization are likely to influence the bioreducibility of the poorly crystalline $\mathrm{Fe}$ (III) oxide and the nature and identity of secondary mineral products.

Coprecipitated silica, organic material, and trace metal cations retard the crystallization of ferrihydrites to goethite and hematite in laboratory suspensions (Cornell and Schwertmann 1996). These constituents bind strongly to hydroxylated Fe(III) centers and inhibit crystallization by functioning as chemical defects that block the formation of continuous arrays of $\mathrm{Fe}$ and $\mathrm{O}$ atom centers. Silica and organic material are believed to play a central role in the stabilization of ferrihydrite in soil (Carlson and Schwertmann 1981; Childs 1992). Natural ferrihydrites from both soil and lake environments invariably contain Si (up to 9 mol\%) and significant organic material (Fortin et al. 1993; Tessier et al. 1996; Perret et al. 2000). Ferrihydrite is most commonly reported in volcanic ash, podzolic, and hydromorphic soils; soils or sediments containing soluble organic materials and silicate; relatively young, water-containing geologic deposits such as Holocene tills; hydrogeologic environments where ferrigenous groundwaters may be oxidized; and as a water column precipitates in seasonably anoxic lakes. Longer weathering periods and higher temperatures promote organic matter oxidation and transformation of ferrihydrite to lepidocrocite, hematite, and/or goethite.

\section{Thermodynamic Stability Under Reducing Conditions}

With decreasing oxidation potential, ferrihydrites become thermodynamically unstable with respect to various ferrous containing solid phases. Magnetite $\left(\mathrm{Fe}_{3} \mathrm{O}_{4}\right)$ and siderite $\left(\mathrm{FeCO}_{3}\right)$ are the most stable ferrous containing mineral solids. The actual phase formed is dependent 


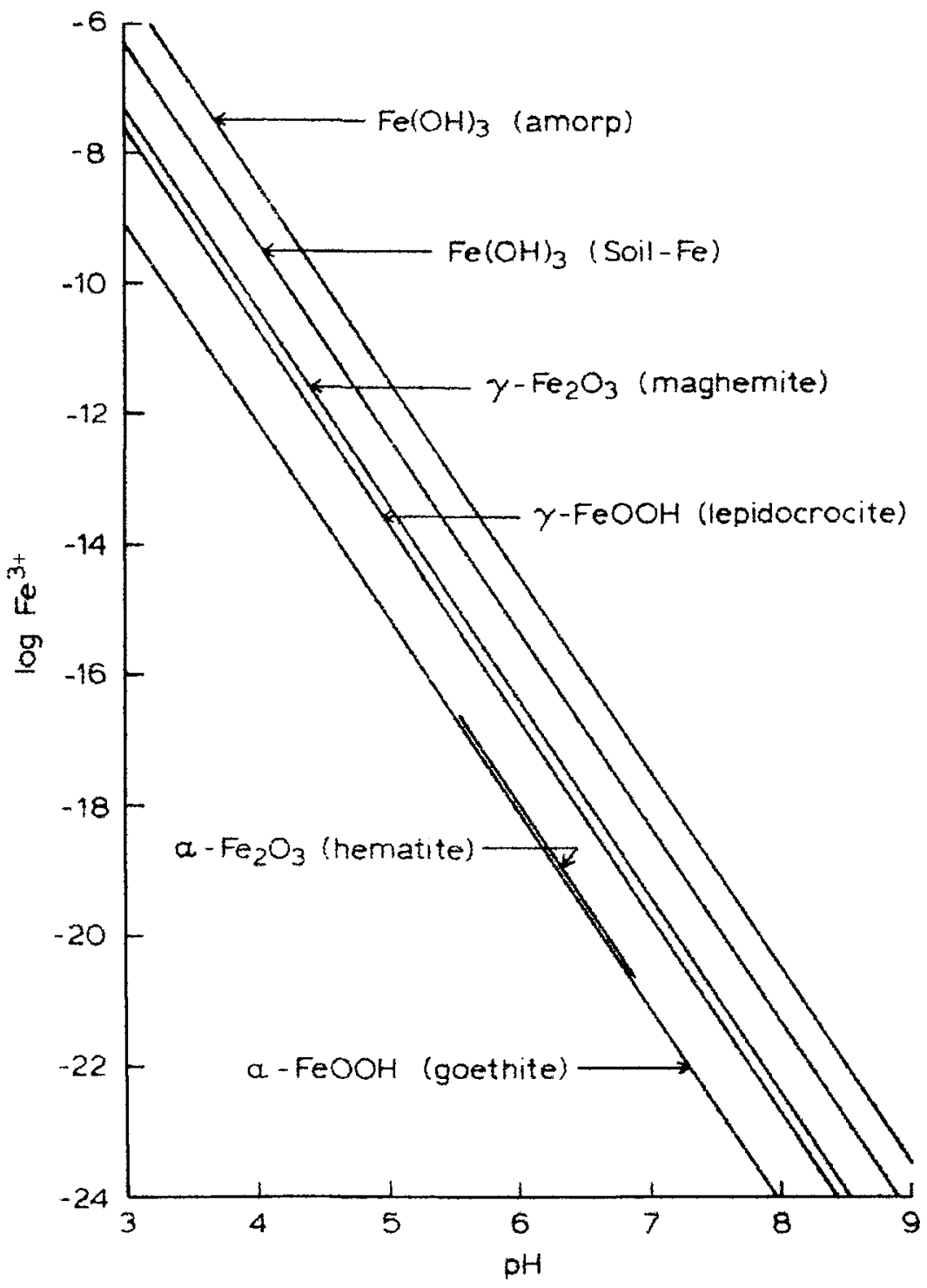

FIGURE 1 Thermodynamic stability of Fe(III) oxides under oxidizing conditions expressed as solubility. The most stable phase is that which supports the lowest $\mathrm{Fe}^{3+}$ activity (e.g., goethite given the used thermodynamic data). From Lindsay (1979). Ferrihydrite is approximated with the stoichiometric formula of $\mathrm{Fe}(\mathrm{OH})_{3}$.

on $\mathrm{pH}$, redox potential (pe or Eh), and carbonate concentration or $\mathrm{CO}_{2}$ partial pressure. These relationships can be conveyed through a stability diagram (Figure 2), of which there are many variants (see, for example, Garrels and Christ 1965; Lindsay 1979; Génin et al. 1998a, 1998b). As shown in Figure 2, a decreasing redox potential at circumneutral pH with $1 \mathrm{mmol} / \mathrm{L}$ of $\mathrm{HCO}_{3}^{-}$favors the thermodynamic transformation of ferrihydrite first to magnetite and then to siderite at lower $\mathrm{Eh}(\approx-.125 \mathrm{~V})$. High $\mathrm{pH}$ tends to favor the formation of $\mathrm{Fe}_{3} \mathrm{O}_{4}$, whereas lower $\mathrm{pH}$ and increasing carbonate favor $\mathrm{FeCO}_{3}$.

Green rusts are mixed valence [Fe(II)/Fe(III)] layered hydroxides that exhibit a pyroaurite structure. In the laboratory they are synthesized by air oxidation of ferrous hydroxide 


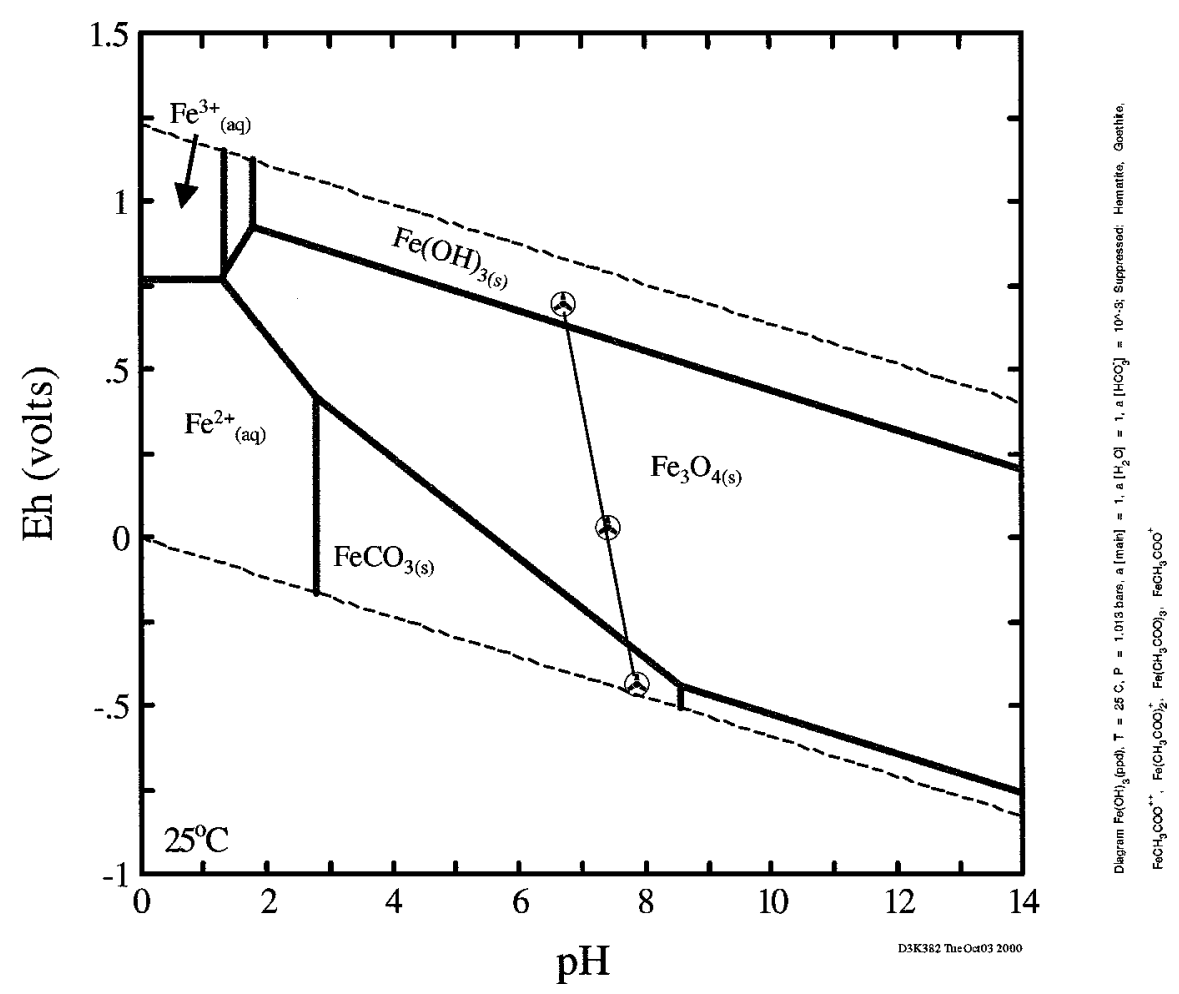

FIGURE 2 Thermodynamic stability of ferrihydrite [stoichiometry assumed as $\mathrm{Fe}(\mathrm{OH})_{3}$ ] with respect to magnetite $\left(\mathrm{Fe}_{3} \mathrm{O}_{4}\right)$ and siderite $\left(\mathrm{FeCO}_{3}\right)$ as a function of redox potential (Eh) and $\mathrm{pH} . \mathrm{HCO}_{3}^{3-}$ was fixed at $10^{-3} \mathrm{~mol} / \mathrm{L}$. A reaction path for the bioreduction of 2-line ferrihydrite at circumneutral $\mathrm{pH}$ is noted that leads to magnetite and siderite formation. Note that the stability field of $\mathrm{Fe}_{3} \mathrm{O}_{4}$ is much reduced if goethite and hematite are considered stable phases rather than $\mathrm{Fe}(\mathrm{OH})_{3}$.

precipitates (Vins et al. 1987; Drissi et al. 1995; Génin et al. 1998a) and by other procedures including reaction of $\mathrm{Fe}_{(\mathrm{aq})}^{2+}$ with ferrihydrite (Hansen and Poulsen 1999). Green rusts are reduced precursors to lepidocrocite ( $\gamma$-FeOOH, Schwertmann and Fechter 1994). Green rusts are reported as microbially induced corrosion products of steel and as reduced Fe-phases in hydromorphic soils (Génin et al. 1998b). They have also been reported as biomineralization products of ferrihydrite (Fredrickson et al. 1998; Parmar et al. 2001) and lepidocrocite. Just as ferrihydrite is a metastable phase to both goethite and hematite, green rusts are metastable to magnetite and siderite (Génin et al. 1998b) and, consequently, do not exhibit a stability region in Figure 2. However, their identification in hydromorphic soils (Trolard et al. 1997; Génin et al. 1998b) indicates temporal periods of environmental stability (or persistent metastability). The reader is directed to Génin et al. (1998a, 1998b) for stability diagrams of green rust in relation to goethite, lepidocrocite, and ferrous iron phases.

\section{Experimental Methods and Procedures}

Ferrihydrite (2-line) was prepared by precipitation with alkali (Cornell and Schwertmann 1991) to $\mathrm{pH} 7-8$ using either ferric nitrate or ferric chloride. Ferrihydrites coprecipitated 
with $\mathrm{Ni}$ or $\mathrm{Co}$

$$
\left[\mathrm{X}_{\mathrm{Me}}=\left(\frac{\mathrm{Me}}{\mathrm{Me}+\mathrm{Fe}}\right)=0.05\right]
$$

where $\mathrm{Me}=\mathrm{Ni}(\mathrm{II})$ or $\mathrm{Co}(\mathrm{II})$ were prepared in a similar manner from acidic salt solutions containing $5 \mathrm{~mol} \% \mathrm{Ni}$ (II) or $\mathrm{Co}(\mathrm{II})$. The solids were washed with either $0.1 \mathrm{~mol} / \mathrm{L} \mathrm{NaClO}_{4}$ or deionized water to remove nitrate or chloride.

Anoxic suspensions of Shewanella putrefaciens strain CN32 (Dr. David Boone, Subsurface Microbial Culture Collection, Portland State University) were prepared as described by Fredrickson et al. (1998). The bacterial cells were harvested at late log growth phase (16 $\mathrm{h}$ growth) and washed three times in the desired $\mathrm{pH}$ buffer solution. Following the third wash, cells were re-suspended in the appropriate buffer at $\mathrm{pH}$ 6.8. Anoxic gas $\left(\mathrm{N}_{2}\right)$ was sparged through the cell suspension for approximately $15 \mathrm{~min}$ prior to inoculation of the ferrihydrite suspensions. The target concentration of $\mathrm{CN} 32$ was $2 \times 10^{8} \mathrm{cfu} / \mathrm{mL}$ in suspension with ferrihydrite, unless otherwise noted.

Several variations of growth media and headspace atmosphere were used depending on experimental objectives (Table 1). After combining the components, the $\mathrm{pH}$ was adjusted to 6.8 using $\mathrm{NaOH}$ and filter sterilized with a $0.2 \mu \mathrm{m}$ syringe filtration system. Growth media was added to the ferrihydrite suspensions the same day as the CN32 cells.

TABLE 1 Media compositions for bioreduction experiments

\begin{tabular}{|c|c|c|c|c|}
\hline \multirow[b]{2}{*}{ Component } & \multicolumn{4}{|c|}{ Concentration $(\mathrm{mmol} / \mathrm{L})$} \\
\hline & Media 1 & Media 2 & Media 3 & Media 4 \\
\hline $\mathrm{KCl}$ & 1.34 & 1.34 & 1.34 & 1.34 \\
\hline $\mathrm{NH}_{4} \mathrm{Cl}$ & 28 & 28 & 28 & 28 \\
\hline $\mathrm{CaCl}_{2}$ & 0.68 & 0.68 & 0.68 & 0.68 \\
\hline $\mathrm{NaClO}_{4}$ & 50 & - & - & - \\
\hline $\mathrm{NaH}_{2} \mathrm{PO}_{4}$ & - & 0.4 & - & - \\
\hline Trace minerals & - & $\operatorname{Yes}^{a}$ & - & - \\
\hline $\mathrm{e}^{-}$donor & Lactic acid; 30 & $\begin{array}{l}\text { Lactic acid; } 0.5 \\
\text { Lactic acid; } 30\end{array}$ & $\begin{array}{l}\mathrm{H}_{2} \\
\mathrm{H}_{2}\end{array}$ & $\begin{array}{l}\mathrm{H}_{2} \\
\mathrm{H}_{2}\end{array}$ \\
\hline $\mathrm{MES}^{b}$ & - & - & 50 & 50 \\
\hline $\mathrm{NaHCO}_{3}$ & - & 30 & - & 30 \\
\hline $\mathrm{PIPES}^{c}$ & 30 & - & - & - \\
\hline Me-HFO & 50 & $\begin{array}{r}50 \\
150\end{array}$ & 20 & 20 \\
\hline $\begin{array}{l}\text { Incubation } \\
\text { temperature }\end{array}$ & $30^{\circ} \mathrm{C}$ & $\sim 23^{\circ} \mathrm{C}$ & $30^{\circ} \mathrm{C}$ & $30^{\circ} \mathrm{C}$ \\
\hline Headspace & $\mathrm{N}_{2}$ & $\mathrm{~N}_{2}: \mathrm{CO}_{2} 80: 20$ & $\begin{array}{c}\mathrm{N}_{2} \\
\mathrm{~N}_{2}: \mathrm{CO}_{2} 99: 1 \\
\mathrm{~N}_{2}: \mathrm{CO}_{2} 98: 2 \\
\mathrm{~N}_{2}: \mathrm{CO}_{2} 95: 5 \\
\mathrm{~N}_{2}: \mathrm{CO}_{2} 90: 10 \\
\mathrm{~N}_{2}: \mathrm{CO}_{2} 80: 20\end{array}$ & $\begin{array}{c}\mathrm{N}_{2} \\
\mathrm{~N}_{2}: \mathrm{CO}_{2} 90: 1 \\
\mathrm{~N}_{2}: \mathrm{CO}_{2} 98: 2 \\
\mathrm{~N}_{2}: \mathrm{CO}_{2} 95: 5 \\
\mathrm{~N}_{2}: \mathrm{CO}_{2} 90: 10 \\
\mathrm{~N}_{2}: \mathrm{CO}_{2} 80: 20\end{array}$ \\
\hline
\end{tabular}

${ }^{a}$ See Fredrickson et al. (1998) Table 1 for a listing of trace minerals and their concentrations.

${ }^{b}$ [2-( $N$-morpholino $)$ thanesulfonic acid].

${ }^{c}[N$-(2-hydroxyethyl)piperazine-N'-(2-ethanesulfonic acid)]. 


\section{Variable Electron Donor (Lactate): Electron Acceptor [Fe(III)] Ratio}

Three combinations of donor/acceptor were used: 0.5/150, 0.5/50, and 30/50 mmol/L lactate/ferrihydrite, respectively (Media 2 in Table 1). The ferrihydrite used in this experiment had been stored for $3 \mathrm{~d}$ since precipitation and the suspension was washed with deionized water prior to initiation of bioreduction. Incubation was performed in $60-\mathrm{mL}$ serum bottles containing $50 \mathrm{~mL}$ of suspension at room temperature $\left(\sim 23^{\circ} \mathrm{C}\right)$ for approximately $20 \mathrm{~d}$. The mineral residue at experiment termination was analyzed by XRD and Mössbauer spectroscopy after drying under anoxic conditions.

\section{Influence of Variable $\mathrm{pCO}_{2}$}

Serum bottles $(160 \mathrm{~mL})$ containing $50 \mathrm{~mL}$ of $20 \mathrm{mmol} / \mathrm{L}$ ferrihydrite suspension in either MES [2-( $N$-morpholino)ethanesulfonic acid] or bicarbonate buffer (Table 1, Media 3 and 4 , respectively) were purged with oxygen-free $\mathrm{N}_{2}$ or mixtures of $\mathrm{N}_{2}: \mathrm{CO}_{2}$ (Table 1, Media 3 and 4) for 15 min prior to inoculation. The serum bottles were sealed with thick butyl rubber stoppers and aluminum crimp seals. Washed cells of CN32 were added through the stoppers to a final concentration of $7.5 \times 10^{7} \mathrm{cfu} / \mathrm{mL}$. Hydrogen gas $\left(40 \mathrm{~cm}^{3}\right)$ was added to the serum bottles to provide an electron donor. The suspensions were incubated at $30^{\circ} \mathrm{C}$ and $50 \mathrm{rpm}$. After $\mathrm{Fe}(\mathrm{III})$ reduction ceased (5 d), concentrations of $\mathrm{Fe}(\mathrm{II})$ in the aqueous phase and weak acid $(0.5 \mathrm{~mol} / \mathrm{L} \mathrm{HCl})$ extract were determined as described by Fredrickson et al. (1998). The suspension $\mathrm{pH}$ was determined under an anoxic atmosphere using a glass combination $\mathrm{pH}$ microelectrode (Microelectrodes, Inc., Bedford, NH). The mineral residue was dried under anoxic conditions and analyzed by XRD.

\section{Influence of Aging and Metal Coprecipitation}

Ferrihydrite and ferrihydrite coprecipitated with 5\% Ni(II) or Co(II) was aged for 7 months at room temperature in $\mathrm{pH} 7.0,0.25 \mathrm{~mol} / \mathrm{L} \mathrm{NaNO}_{3}$. The aged materials were washed extensively to remove $\mathrm{NO}_{3}$ and were then inoculated with $\mathrm{CN} 32$ in Media 1 (Table 1) to evaluate the comparable reducibility of the aged to the unaged materials. Ten $\mathrm{mL}$ of suspension in a $20-\mathrm{mL}$ headspace vial were incubated with $\mathrm{CN} 32\left(10^{8} \mathrm{cfu} / \mathrm{mL}\right)$ at $30^{\circ} \mathrm{C}$ for $33 \mathrm{~d}$. The bioreduced suspensions were handled under an anoxic atmosphere in an environmental chamber. Approximately $6.8 \mathrm{~mL}$ of a composite sample from five replications were filtered, washed, and dried under anoxic conditions in preparation for Mössbauer and XRD analysis.

\section{Mixtures of Fe(III) Oxides}

A portion of freshly precipitated 2-line ferrihydrite suspension was heated at $70^{\circ} \mathrm{C}$ for $16 \mathrm{~d}$ (Ford et al. 1997) to produce a ferric oxide mixture containing $18 \%$ ferrihydrite, $42 \%$ goethite, and $40 \%$ hematite as determined by spectral area analysis of the Mössbauer pattern. Ten $\mathrm{mL}$ of suspension in a $20 \mathrm{~mL}$ headspace vial was incubated with $\mathrm{CN} 32$ at $30^{\circ} \mathrm{C}$ for $33 \mathrm{~d}$ in Media 1 (Table 1). The bioreduced mineral residue was prepared for Mössbauer and XRD analysis as described previously.

\section{Mössbauer Analyses}

Subsamples of the unreduced and bioreduced ferrihydrites were analyzed using ${ }^{57} \mathrm{Fe}$ Mössbauer spectroscopy. The bioreduced mineral residues were filtered; washed with deoxygenated, deionized $\mathrm{H}_{2} \mathrm{O}$ and then acetone; and then dried under anoxic conditions. The dried powders (unreduced and bioreduced) were mixed with petroleum jelly, sealed with tape or Arlon polymer, and left in the anoxic chamber until analysis. Spectra were collected 
at variable temperatures using $\sim 50 \mathrm{mCi}(1.85 \mathrm{MBq}){ }^{57} \mathrm{Co} / \mathrm{Rh}$ single-line thin sources. The Mössbauer bench (MB-500; WissEL, Germany) was equipped with a dual Mössbauer drive system to gather data simultaneously for two experiments. The velocity transducer (MVT-1000; WissEL) was operated in the constant-acceleration mode $(23 \mathrm{~Hz}, \pm 10 \mathrm{~mm} /$ $\mathrm{sec})$. Data were acquired on 1,024 channels and then folded to 512 channels to give a flat background and a zero-velocity position corresponding to the center shift (CS or $\delta$ ) of a metallic-Fe foil at room temperature. Calibration spectra were obtained with a $20 \mu \mathrm{m}$ thick $\alpha$-Fe foil (Amersham, England) placed in exactly the same position as the samples to minimize any geometry error. The transmitted radiations were recorded with the Ar-Kr proportional counters. The unfolded spectra were folded and evaluated with the Recoil program (University of Ottawa, Canada) using the Voigt-based hyperfine parameter distribution method (Rancourt and Ping 1991). The intensity ratio of the $h_{1} / h_{3}$ and $h_{2} / h_{3}$ lines of the sextet were fixed at 3 and 2 , respectively.

\section{Results and Discussion}

A number of factors have been observed to influence the secondary mineral suite resulting from the bioreduction of ferrihydrite including: aqueous chemistry, electron donor and acceptor concentrations, extent of ferrihydrite aging, adsorbed or coprecipitated ions, and co-associated crystalline Fe(III) oxides. Here, we show the influence of these factors on the identity and morphology of biomineralization products formed. DMRB function primarily at circumneutral $\mathrm{pH}$ range and our evaluation was performed in the $\mathrm{pH}$ range of 6-8. Through this assessment we identified the primary geochemical and microbiologic controls on biomineralization.

\section{Laboratory Models}

Biotransformations of ferrihydrite have been commonly studied at circumneutral $\mathrm{pH}$ in media buffered with either PIPES (1,4-piperazinediethanesulfonic acid) or bicarbonate buffer to maintain constant hydrogen ion activity. Other buffers such as MES [2-(4morpholine )ethane sulfonic acid] are used less frequently to access lower $\mathrm{pH}$. The bioreduction reactions approximated below with hydrogen or lactate as the electron donor consume protons and elevate the suspension $\mathrm{pH}$ with time, especially when initial $\mathrm{Fe}$ (III) concentrations are high and bioreduction is extensive. Again, we use the most simplistic representation of ferrihydrite stoichiometry for ease of reaction balancing.

$$
\begin{aligned}
& \mathrm{Fe}(\mathrm{OH})_{3(\mathrm{~s})}+1 / 2 \mathrm{H}_{2}+2 \mathrm{H}^{+}=\mathrm{Fe}^{2+}+3 \mathrm{H}_{2} \mathrm{O} \\
& \mathrm{Fe}(\mathrm{OH})_{3(\mathrm{~s})}+1 / 4 \mathrm{CH}_{3} \mathrm{CHOHCOO}^{-}+7 / 4 \mathrm{H}^{+} \\
& \quad=\mathrm{Fe}^{2+}+1 / 4 \mathrm{CH}_{3} \mathrm{COO}^{-}+1 / 4 \mathrm{HCO}_{3}^{-}+10 / 4 \mathrm{H}_{2} \mathrm{O}
\end{aligned}
$$

Increasing $\mathrm{pH}$ promotes the formation of oxide, hydroxide, carbonate, and phosphate mineral phases that are observed as biomineralization products. The composition of media used for bioreduction studies vary (see, for example, Kostka and Nealson 1995; Fredrickson et al. 1998; Zachara et al. 2001), and may include trace metals (with $\mathrm{SO}_{4}^{2-}$ as the charge compensating anion), vitamins, $\mathrm{N}\left(\mathrm{NH}_{4} \mathrm{Cl}, \approx 1.0 \mathrm{mmol} / \mathrm{L}\right), \mathrm{P}\left(\mathrm{PO}_{4}^{3-}\right.$ at $\left.0.4-4.0 \mathrm{mmol} / \mathrm{L}\right)$, and $\mathrm{K}(\mathrm{KCl}, \approx 1.0 \mathrm{mmol} / \mathrm{L})$ depending on whether the media is intended to support growth or not. Media preparations containing trace metals and vitamins typically contain in excess of $1.0 \mathrm{mmol} / \mathrm{L} \mathrm{SO}_{4}^{2-}$. Although $\mathrm{SO}_{4}^{2-}$ does not generally function as an electron acceptor for DMRB, it may enhance the formation of green rust. 
To date, the bioreduction of poorly crystalline Fe(III) oxide has been studied primarily with 2-line ferrihydrite as the electron acceptor. The preferred synthesis method has been by hydrolysis of acid ferric salt solutions. Although natural ferrihydrites often form by oxidation of ferrous containing waters (Childs 1992), this synthesis route has not often been applied for specimen ferrihydrite because of the potential for joint lepidocrocite precipitation. When facultative DMRB are to be studied, many investigators avoid the use of $\mathrm{Fe}\left(\mathrm{NO}_{3}\right)_{3}$ salts for hydrolytic 2-line ferrihydrite synthesis, in favor of $\mathrm{FeCl}_{3} \cdot \mathrm{nH}_{2} \mathrm{O}$, to avoid potential $\mathrm{NO}_{3}^{-}$carryover from the solids that could provide facultative DMRB with an alternative electron acceptor. The chloride ion, however, promotes akaganeite $(\beta-\mathrm{FeOOH})$ formation below $\mathrm{pH} 5$ (Schwertmann and Cornell 1991), and the resulting solid must be analyzed carefully to confirm the presence of the desired Fe(III) oxide. However, little attention has generally been paid to documenting the true mineralogic nature of the starting material which may vary with aging time and other vagaries of the synthesis process including base addition rate, $\mathrm{pH}$, temperature, electrolyte ion, and so forth.

\section{Aqueous Chemistry}

The solution and media conditions exert a strong effect on the nature of ferrous-containing biomineralization products formed from 2-line ferrihydrite (Table 2). As discussed later, the electron donor to acceptor ratio is also important, and all studies discussed in this section utilized $30 \mathrm{mmol} / \mathrm{L}$ to $50 \mathrm{mmol} / \mathrm{L}$ ferrihydrite as the electron acceptor and excess electron donor in the form of lactate or $\mathrm{H}_{2(\mathrm{~g})}$.

Bicarbonate buffer promotes siderite formation $\left(\mathrm{FeCO}_{3}\right)$ through mass action effects [e.g., $\mathrm{Fe}^{2+}+\mathrm{HCO}_{3}^{-}=\mathrm{FeCO}_{3(\mathrm{~s})}+\mathrm{H}^{+}$] (Table 2). Abiotic studies indicate that siderite precipitation is $98 \%$ complete in $4 \mathrm{~h}$ when mmol/L solutions of $\mathrm{Fe}^{2+}$ and bicarbonate are mixed at pH 7.2 (Thornber and Nickel 1976). This precipitation rate is comparable to, or possibly faster than, the biotic reduction rate (Liu et al. 2001a). It was not uncommon in the studies of Fredrickson et al. (1998) to observe complete conversion of poorly crystalline $\mathrm{Fe}$ (III) to siderite. Biogenic siderite is observed as rhombohedral crystallites ranging in size from 0.5 to $2.0 \mu \mathrm{m}$ (Figure 3a).

Fine-grained magnetite is a most common product of the bioreduction of ferrihydrite by DMRB (Lovley et al. 1987; Mortimer and Coleman 1997; Fredrickson et al. 1998). Magnetite exhibits a large stability field relative to 2-line ferrihydrite as the redox potential

TABLE 2 Secondary solid phases resulting from the bioreduction of 2-line ferrihydrite by $S$. putrefaciens, strain CN32 from Fredrickson et al. (1998)

\begin{tabular}{|c|c|c|c|c|}
\hline Buffer & $\mathrm{HCO}_{3}{ }^{a}$ & $\mathrm{HCO}_{3}{ }^{a}$ & PIPES $^{a}$ & $\mathrm{PIPES}^{a}$ \\
\hline Final $\mathrm{pH}^{b}$ & 7.4 & 7.1 & 7.8 & 7.1 \\
\hline $\mathrm{PO}_{4}^{3-c}$ & $4.0 \times 10^{-3}$ & 0 & $4.0 \times 10^{-3}$ & 0 \\
\hline $\begin{array}{l}\% \text { of total } \mathrm{Fe}(\mathrm{II}) \\
\text { reduced }^{d}\end{array}$ & $62 \%$ & $33 \%$ & $28 \%$ & $11 \%$ \\
\hline $\begin{array}{l}\text { Secondary mineral } \\
\text { phases }^{e}\end{array}$ & $\begin{array}{l}\text { Siderite, } \\
\quad \text { vivianite }\end{array}$ & $\begin{array}{l}\text { Siderite, } \\
\text { magnetite }^{f}\end{array}$ & $\begin{array}{l}\text { Poorly } \\
\text { crystalline }^{g}\end{array}$ & Magnetite \\
\hline $\begin{array}{l}{ }^{a} \text { Buffer concentrati } \\
{ }^{b} \text { After } 20 \mathrm{~d} \text { incubat } \\
{ }^{\circ} \text { Final concentratio } \\
{ }^{d} \text { After } 20 \mathrm{~d} \text { incubat } \\
{ }^{e} \text { By XRD. } \\
{ }^{f} \text { Magnetite is a mi } \\
{ }^{8} \text { Greenith-ble }\end{array}$ & $\begin{array}{l}n \text { was } 30 \mathrm{mmo} \\
\text { n. } \\
\text { was at least } 10 \\
\text { on. } \\
\text { or component. }\end{array}$ & $\begin{array}{l}\text { L. } \\
\times \text { less in both tre }\end{array}$ & nents. & \\
\hline
\end{tabular}


a. Siderite $\left(\mathrm{FeCO}_{3}\right)$

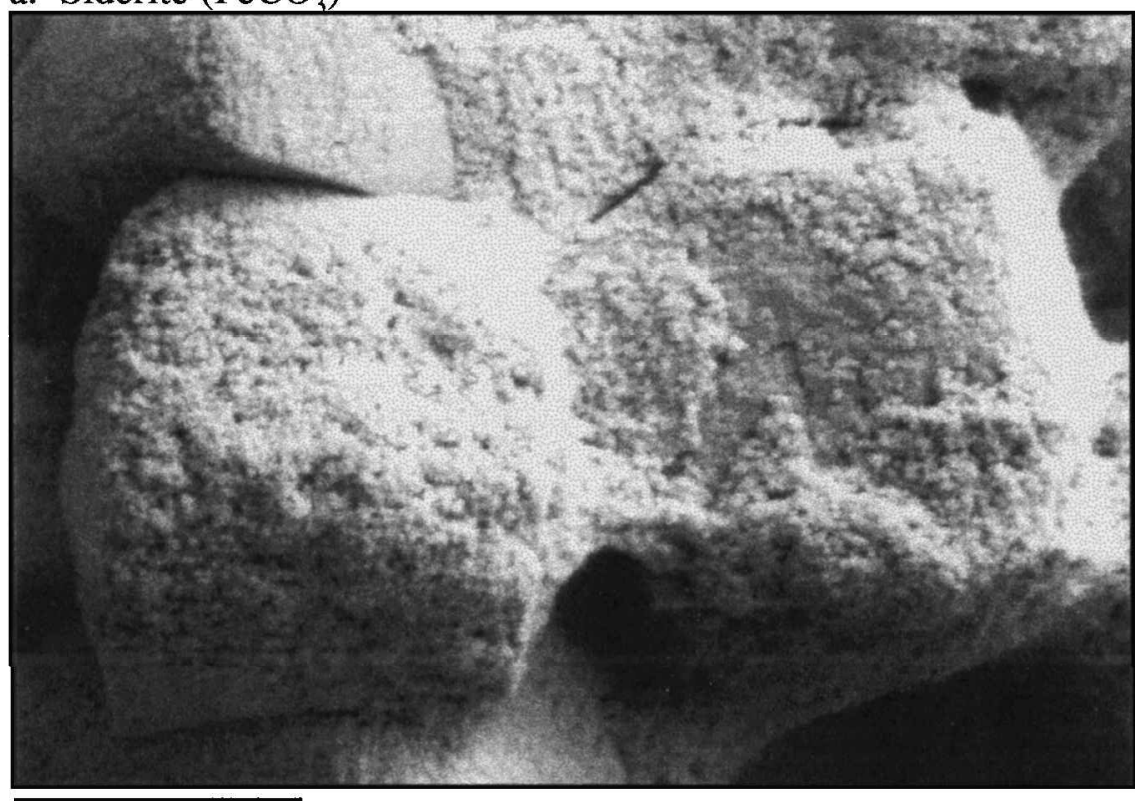

$1 \mu \mathrm{m}$

b. Magnetite $\left(\mathrm{Fe}_{3} \mathrm{O}_{4}\right)$

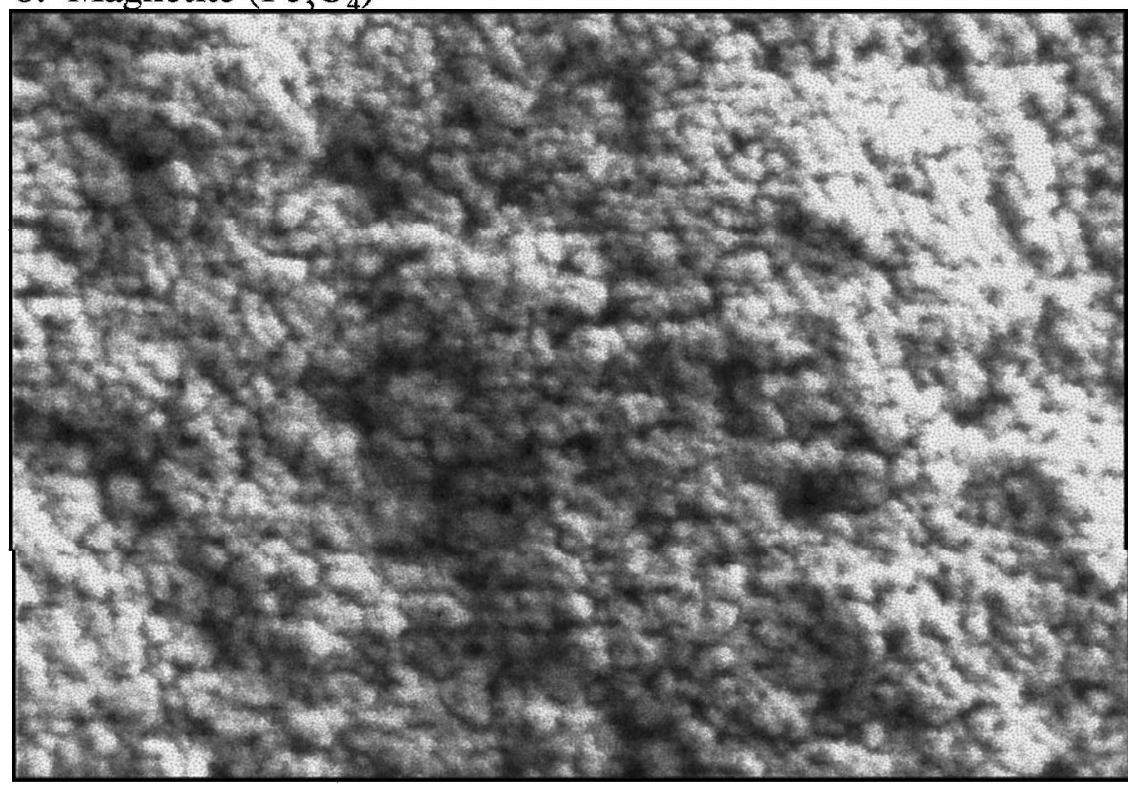

$500 \mathrm{~nm}$

FIGURE 3 Scanning electron micrographs of biogenic magnetite and siderite coated with ferrihydrite. Samples are from the experiment summarized in Figure 4. Scale as noted. 
is decreased (Figure 2), and is a more stable phase than ferrihydrite under anoxic conditions. Biogenic magnetite exists as aggregates of nm-sized crystallites (Figure 3b; Fredrickson et al. 1998), retaining morphologic and size features of 2-line ferrihydrite. The size and morphology of biogenic magnetite indicates that it forms by topotactic conversion of 2-line ferrihydrite driven by Fe(II) sorption (Ardizzone and Formaro 1983; Mann et al. 1989; Fredrickson et al. 1998). Biogenic magnetite forms in both bicarbonate and organic acid buffers (Mortimer and Coleman 1997; Fredrickson et al. 1998).

An anoxic suspension of 2-line ferrihydrite that is inoculated with DMRB and spiked with an electron donor at circumneutral $\mathrm{pH}$ rapidly enters the stability field of magnetite regardless of whether bicarbonate is present or not (e.g., note reaction path in Figure 2). Magnetite can form rapidly under requisite bioreductive conditions, which appears to involve a moderate $\mathrm{Fe}$ (II) flux that sorbs to and reacts with the residual ferrihydrite. The formation of magnetite sequesters the remaining $\mathrm{Fe}$ (III) in a relatively stable, inverse spinel structure. It is not known whether biogenic magnetite, once formed, can be bioreduced to siderite, or whether siderite formation requires specific conditions such as a high respiration/Fe(II) flux rate that precludes magnetite formation. Kostka and Nealson (1995) showed that magnetite bioreduction by $S$. putrefaciens was feasible below $\mathrm{pH} 7$ in a specific medium formulation (MR-1). The results of Dong et al. (2000) indicated that biogenic magnetite could be bioreduced by DMRB to siderite, but small quantities of residual ferrihydrite in the magnetite may have contributed to siderite formation.

An example of the conditions leading to magnetite and siderite formation is shown in Figure 4 where the bioreduction (by S. putrefaciens, strain CN32) of 2-line ferrihydrite (20 mmol/L) was studied as a function of $\mathrm{N}_{2}: \mathrm{CO}_{2}$ ratio (100:0-80:20) in MES and bicarbonate buffers with $\mathrm{H}_{2}$ as the electron donor. In all cases, the mineral/buffer suspension was equilibrated with gas before inoculation with organisms and e-donor. The biomineralization products that resulted (as determined by XRD, data not shown) were almost identical in both buffers. Magnetite was observed as the primary product below a $\mathrm{N}_{2}: \mathrm{CO}_{2}(\mathrm{~g})$ ratio of approximately 90:10. At a ratio of 90:10, a mixture of phases was observed including crystalline $\mathrm{Fe}$ (III) oxides (goethite, lepidocrocite) as well as magnetite and siderite. At a $\mathrm{N}_{2}: \mathrm{CO}_{2}$ ratio of 80:20, siderite was the only bioreduction product. The $\mathrm{pH}$ of all treatments increased with bioreduction. There was not a direct correlation between $\mathrm{Fe}$ (II) produced and $\mathrm{pH}$ increase because protons were also released by mineral precipitation.

Model calculations and chemical analyses showed that both these buffer systems were in equilibrium with $\mathrm{CO}_{2(\mathrm{~g})}$ and contained equivalent bicarbonate concentrations at the same $\mathrm{pH}$ (Table 3). The results strongly indicate that the formation of siderite does not proceed through a magnetite intermediate. Rather, higher $\mathrm{HCO}_{3}^{-}$concentrations $(18-40 \mathrm{mmol} / \mathrm{L})$ appear to prevent topotactic conversion to magnetite through aqueous complexation of $\mathrm{Fe}$ (II), or surface complexation of $\mathrm{HCO}_{3}^{-}$that inhibits $\mathrm{Fe}_{3} \mathrm{O}_{4}$ formation and/or accelerates nucleation of $\mathrm{FeCO}_{3(\mathrm{~s})}$. Under such conditions, $\mathrm{FeCO}_{3(\mathrm{~s})}$ precipitates as large rhombohedral precipitates in a groundmass of fine-grained ferrihydrite, indicating homogeneou s precipitation after the initial nucleation phase (Figure 3a). The results indicated that small differences in initial and final $\mathrm{pH}$ may influence the identity of the secondary products, but more definitive studies are required. The Figure 4 data do not allow comment on whether the respiration/reduction rate varied between the treatments with different $\mathrm{CO}_{2}(\mathrm{~g})$ pressures and/or whether kinetic issues were important.

The use of $\mathrm{mmol} / \mathrm{L}$ concentrations of $\mathrm{PO}_{4}^{3-}$ as a nutrient often leads to vivianite $\left[\mathrm{Fe}_{3}\left(\mathrm{PO}_{4}\right)_{2} \cdot 8 \mathrm{H}_{2} \mathrm{O}\right]$ precipitation as $\mathrm{Fe}(\mathrm{II})$ is produced during bioreduction. Much of the added $\mathrm{PO}_{4}^{3-}$ is initially sorbed by the Fe(III) oxide (Fredrickson et al. 1998, 2001), and the sorbed $\mathrm{PO}_{4}^{3-}$ appears to be directly incorporated into vivianite during bioreduction. Vivianite precipitates rapidly in DMRB suspensions at circumneutral $\mathrm{pH}$ (Zachara 


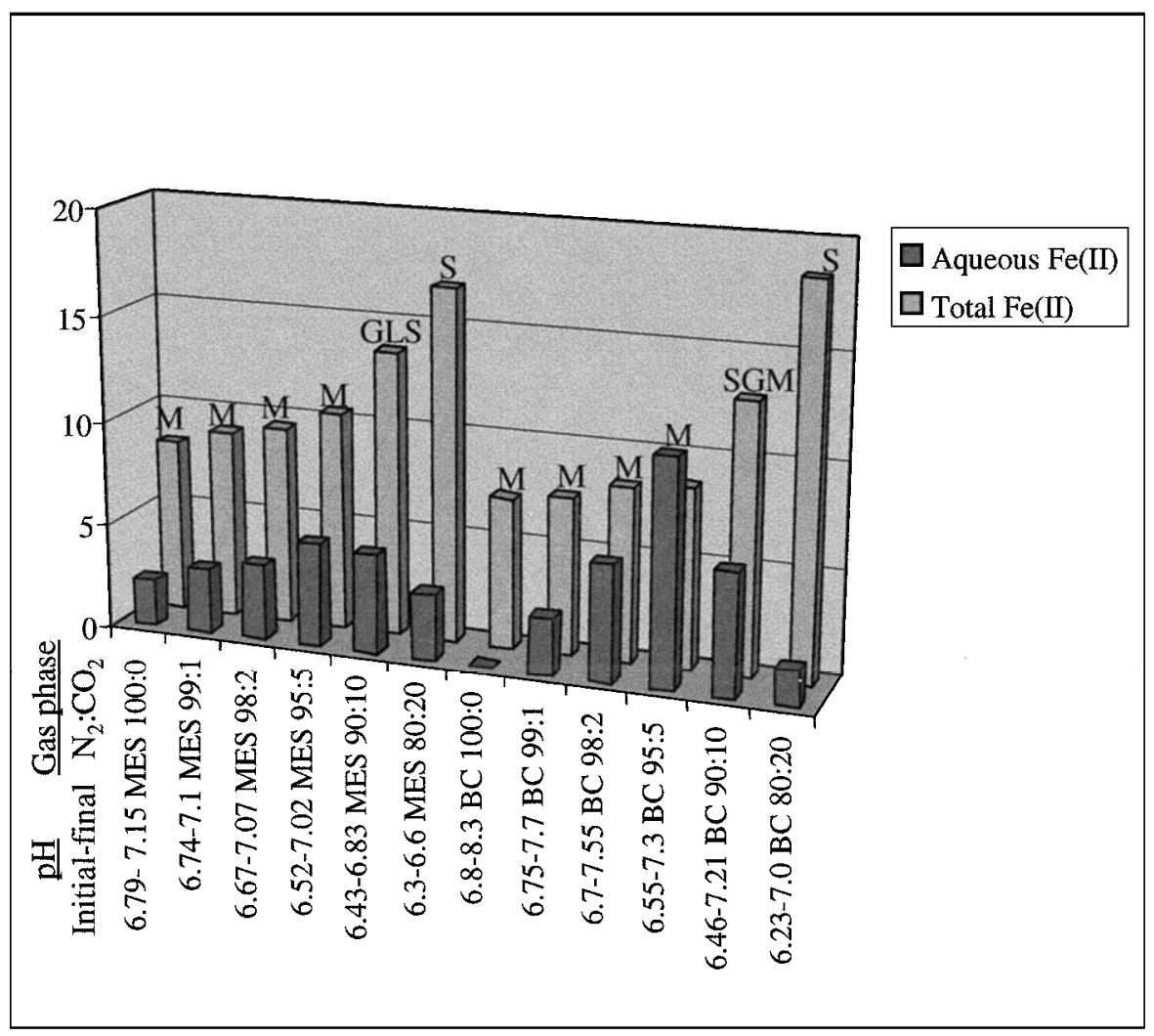

FIGURE 4 Total $(0.5 \mathrm{~N} \mathrm{HCl}$ extractable) and aqueous $\mathrm{Fe}(\mathrm{II})$ in a bioreduction experiment with 2-line ferrihydrite $(20 \mathrm{mmol} / \mathrm{L}), \mathrm{H}_{2}$ gas, variable $\mathrm{CO}_{2}$ pressure, and either bicarbonate $(\mathrm{BC})$ or MES buffer. Observed biomineralization products identified by letter: $\mathrm{M}=$ magnetite, $\mathrm{G}=$ goethite, $\mathrm{L}=$ lepidocrocite, and $\mathrm{S}=$ siderite. Initial and final $\mathrm{pH}$ values and gas pressure are as noted. Carbonate concentrations are given in Table 2.

et al. 1998), typically forming 5-10 $\mu$ m prismatic crystallites. Its precipitation is observed in both bicarbonate and organic acid buffers. Because nutrient $\mathrm{PO}_{4}^{3-}$ is typically added at concentrations well below that of the poorly crystalline $\mathrm{Fe}$ (III) oxide, the vivianite is found in association with other biogenic solids. The low solubility of vivianite (Al-Borno and Tomson 1994) combined with its rapid precipitation kinetics allows it to form before siderite in bicarbonate buffer (Zachara et al. 1998). There is no evidence for direct microbial involvement in the precipitation of either siderite or vivianite other than through $\mathrm{Fe}$ (II) supply.

In addition to promoting vivianite formation, $\mathrm{PO}_{4}^{3-}$ inhibits the nucleation of magnetite in both abiotic (Couling and Mann 1985) and DMRB inoculated (Fredrickson et al. 1998) systems. The inhibitory effect may result from the strong surface complexation of $\mathrm{PO}_{4}^{3-}$ that impedes the internal recrystallization of 2-line ferrihydrite to magnetite (Couling and Mann 1985). The adsorption density and aqueous concentration range over which $\mathrm{PO}_{4}^{3-}$ inhibits magnetite formation has not been established. Green rust (in association with vivianite) has been observed as a biomineralization product of 2-line ferrihydrite $(50 \mathrm{mmol} / \mathrm{L})$ only in the presence of $\mathrm{PO}_{4}^{3-}(4.4 \mathrm{mmol} / \mathrm{L})$ and AQDS $(0.10 \mathrm{mmol} / \mathrm{L}$, anthraquinone disulfonate, an electron shuttle) in carbonate-deficient buffer (Fredrickson et al. 1998; Figure 5). The formation of metastable green rust is apparently facilitated by $\mathrm{PO}_{4}^{3-}$ that inhibits magnetite formation; AQDS that accelerates the respiration, reduction, and $\mathrm{Fe}(\mathrm{II})$ supply rate; and 
TABLE 3 Total $\mathrm{CO}_{2}(\mathrm{mmol} / \mathrm{L})$ in aqueous phase with variable $\mathrm{pH}$ and $\mathrm{CO}_{2}$ partial pressure (atm)*

\begin{tabular}{|c|c|c|c|c|c|c|}
\hline $\mathrm{pH}$ & $\mathrm{PCO}_{2}$ & 0.01 & 0.02 & 0.05 & 0.1 & 0.2 \\
\hline 6.0 & & 0.49 & 0.98 & 2.45 & 4.90 & 9.80 \\
\hline 6.1 & & 0.52 & 1.05 & 2.64 & 5.29 & 10.58 \\
\hline 6.2 & & 0.57 & 1.15 & 2.89 & 5.78 & 11.57 \\
\hline 6.3 & & 0.64 & 1.28 & 3.20 & 6.40 & 12.81 \\
\hline 6.4 & & 0.71 & 1.43 & 3.59 & 7.19 & 14.38 \\
\hline 6.5 & & 0.81 & 1.63 & 4.08 & 8.17 & 16.35 \\
\hline 6.6 & & 0.94 & 1.88 & 4.70 & 9.41 & 18.83 \\
\hline 6.7 & & 1.09 & 2.19 & 5.48 & 10.97 & 21.95 \\
\hline 6.8 & & 1.29 & 2.58 & 6.47 & 12.94 & 25.88 \\
\hline 6.9 & & 1.54 & 3.08 & 7.70 & 15.41 & 30.83 \\
\hline 7.0 & & 1.85 & 3.70 & 9.26 & 18.53 & 37.06 \\
\hline 7.1 & & 2.24 & 4.49 & 11.22 & 22.45 & 44.90 \\
\hline 7.2 & & 2.73 & 5.47 & 13.69 & 27.39 & 54.78 \\
\hline 7.3 & & 3.36 & 6.72 & 16.80 & 33.61 & 67.23 \\
\hline 7.4 & & 4.14 & 8.29 & 20.72 & 41.45 & 82.90 \\
\hline 7.5 & & 5.13 & 10.26 & 25.66 & 51.32 & 102.64 \\
\hline
\end{tabular}

*The data in the table are specific to Figure 4. Total aqueous $\mathrm{CO}_{2}$ only includes $\mathrm{H}_{2} \mathrm{CO}_{3}, \mathrm{HCO}_{3}^{-}, \mathrm{CO}_{3}^{2-}$ species, equilibrium constants at $25^{\circ} \mathrm{C}$ were used in calculations, and the calculated values were not corrected for ionic strength.

$\mathrm{SO}_{4}^{2-}$ (from the trace metal solution), $\mathrm{Cl}^{-}$(from the nutrient solution), and $\mathrm{CO}_{3}^{2-}$ (from lactate oxidation) to function as intercalating anions. An abiotic analogue study observed the formation of green rust under comparable conditions of $\mathrm{Fe}(\mathrm{II}), \mathrm{PO}_{4}^{3-}, \mathrm{pH}$, and ferrihydrite concentration (Hansen and Poulsen 1999). As noted by Hansen and Poulsen (1999), vivianite, not green rust, is the stable end product and the long-term persistence of green rust is determined by the available $\mathrm{PO}_{4}^{3-}$ concentration. A phosphate deficiency relative to vivianite stoichiometry will stabilize green rust.

\section{Electron Acceptor to Donor Ratio}

A wide range of electron acceptor to donor ratios may exist in soil or sediment. The electron donor may be in excess or deficient relative to the poorly crystalline $\mathrm{Fe}$ (III) oxide fraction. Electron donors for DMRB include $\mathrm{H}_{2(\mathrm{~g})}$ and low molecular weight organic acids (e.g., lactate, acetate) that are typically in low concentration in porewater or groundwater. Because of their low concentration (e.g., $<10^{-4} \mathrm{~mol} / \mathrm{L}$ ) and the large solid-liquid ratio of natural soil-water systems (typically $>2 \mathrm{~kg} / \mathrm{L}$ ), the electron donor may often be deficient relative to the electron acceptor when concentrations at a single time point are compared. However, because the electron donors are water-soluble, advective flux over longer time periods in natural systems may supply total concentrations of electron donor that exceed the stationary concentration of poorly crystalline $\mathrm{Fe}(\mathrm{III})$ oxides.

The electron donor to acceptor ratio can affect the biomineralization products resulting from the action of DMRB on 2-line ferrihydrite. Shown in Figure 6 are transmission Mössbauer spectra of 2-line ferrihydrite aged for $8 \mathrm{~h}$ (a), and after contact with $S$. putrefaciens, CN32, for $20 \mathrm{~d}$ under anoxic conditions in $30 \mathrm{mmol} / \mathrm{L}$ bicarbonate buffer with lactate as the electron donor $(b-e)$. Three electron donor:acceptor ratios are shown, 

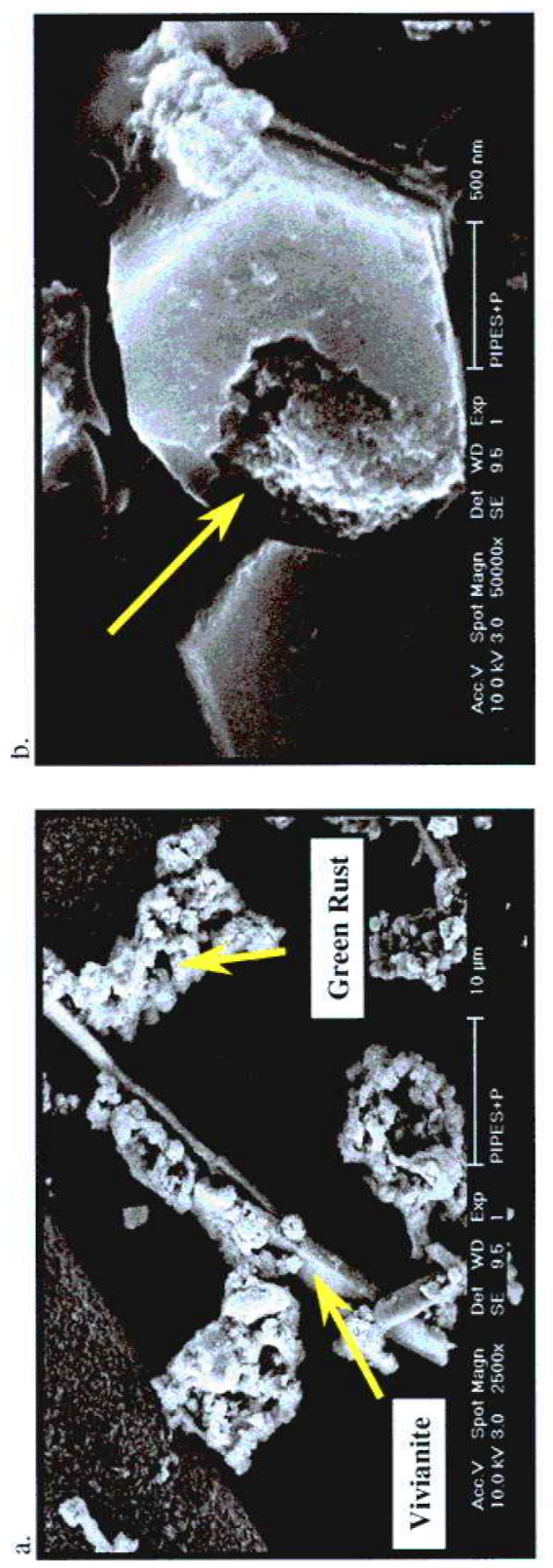

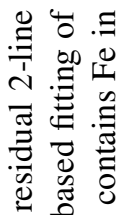

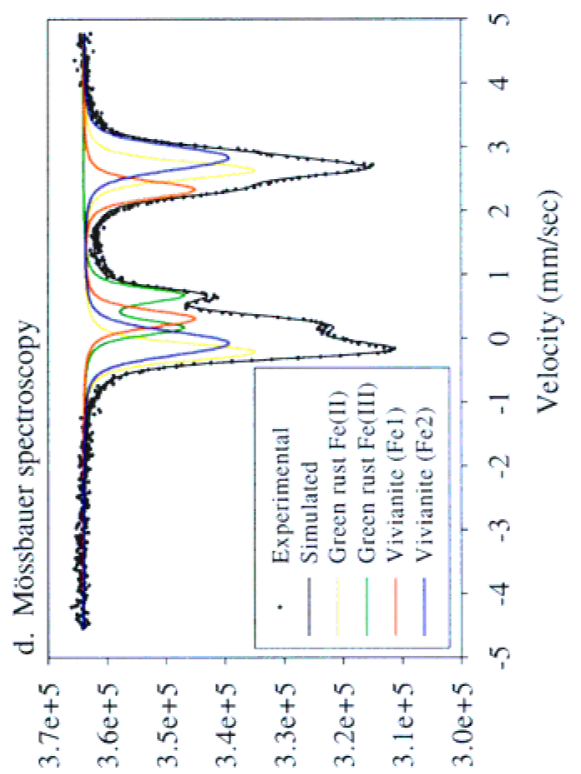

我

ว $>$ क

क

.

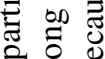

능

ఏ छ

류

कू के है

$\approx$ षे

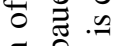

.

胥 :

可

छิ

율 흘

อิ

象: 步

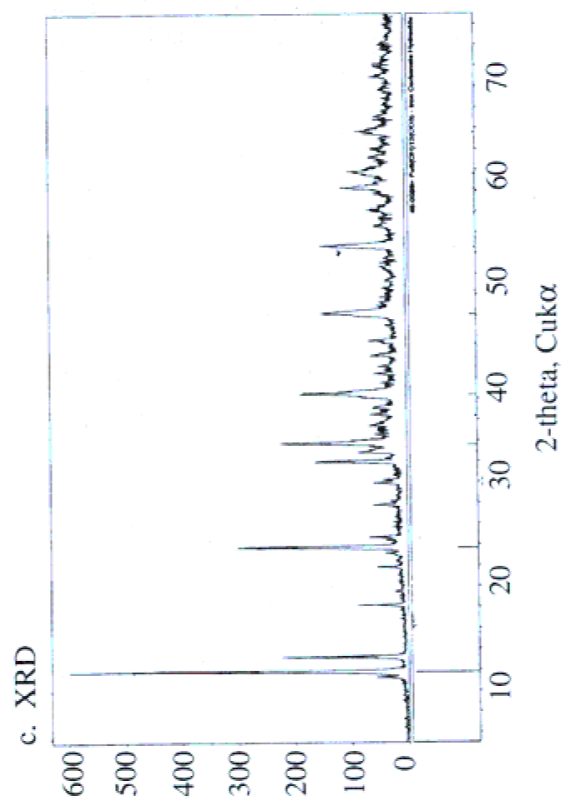

(sıuno. ) ) KıเsuอฺU .స్ ठำ $\rightarrow \frac{0}{x}$ 을

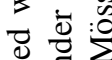
. गु 芯 范 $\vec{\Xi}$ छ

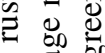
ญี का ए () 芯总

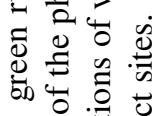
. 응ㅇㅇㄹ n

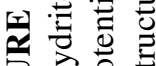
금

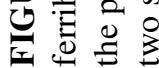




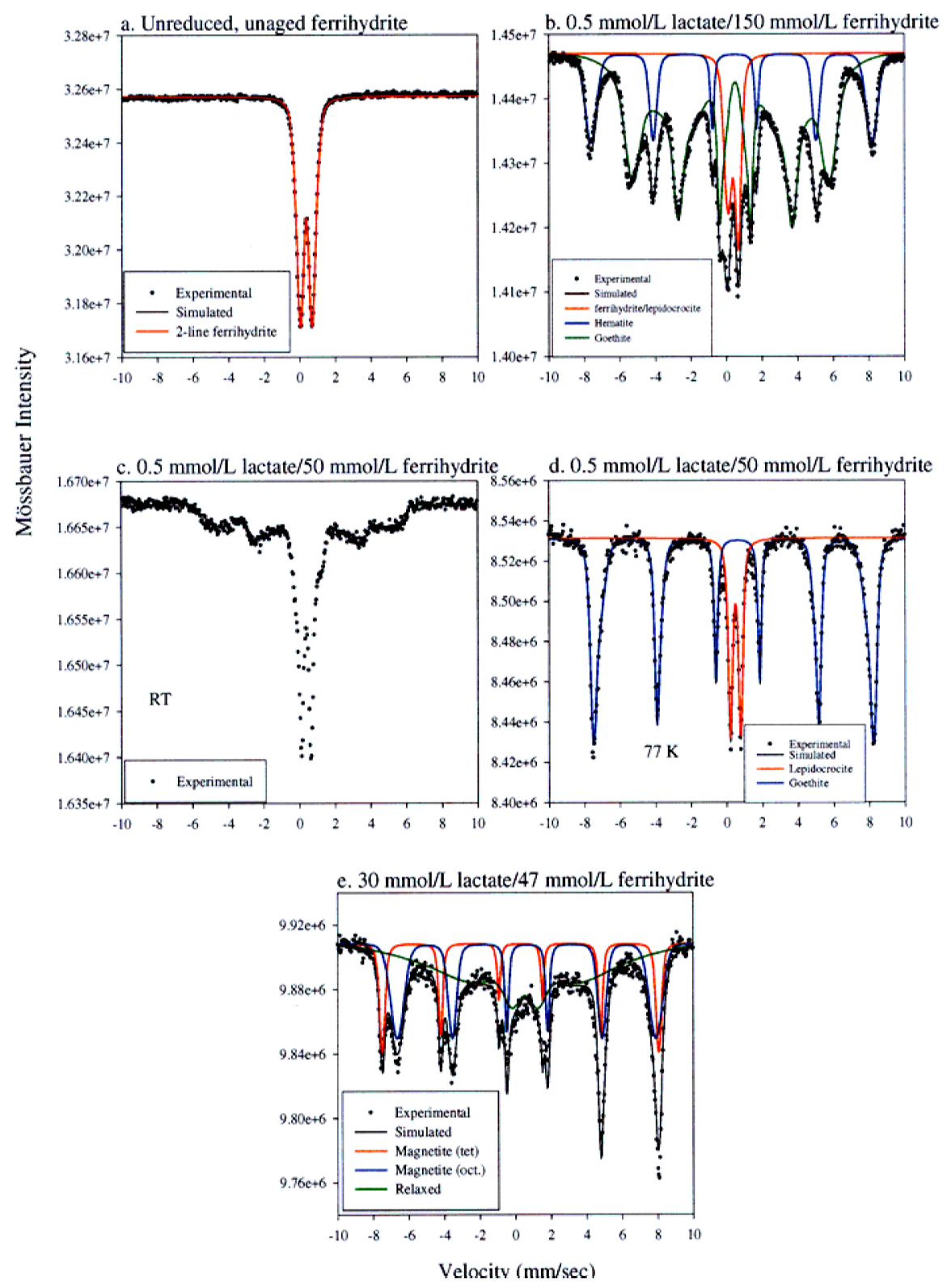

FIGURE 6 Room temperature (RT) Mössbauer spectrum of 2-line ferrihydrite, (a) and of ferrihydrite subject to bioreducing conditions (in $30 \mathrm{mmol} / \mathrm{L}$ bicarbonate buffer) with variable e-donor:acceptor ratios (b-e). (b) RT spectrum of $0.5 \mathrm{mmol} / \mathrm{L}$ lactate and $150 \mathrm{mmol} / \mathrm{L}$ ferrihydrite, (c) RT spectrum of $0.5 \mathrm{mmol} / \mathrm{L}$ lactate and $50 \mathrm{mmol} / \mathrm{L}$ ferrihydrite, (d) $77 \mathrm{~K}$ spectrum of $0.5 \mathrm{mmol} / \mathrm{L}$ lactate and $50 \mathrm{mmol} / \mathrm{L}$ ferrihydrite, and (e) RT spectrum of $30 \mathrm{mmol} / \mathrm{L}$ lactate and $47 \mathrm{mmol} / \mathrm{L}$ ferrihydrite. Voight-based model simulations are shown by solid line along with contributing mineral phases. Mag(TET) and Mag(OCT) refer to the tetrahedral and octahedral sites of magnetite. 
from deficient $(0.5 \mathrm{mmol} / \mathrm{L}$ lactate $/ 150 \mathrm{mmol} / \mathrm{L}$ ferrihydrite $)$ to excess $(30 \mathrm{mmol} / \mathrm{L}$ lactate/ $47 \mathrm{mmol} / \mathrm{L}$ ferrihydrite). The Mössbauer spectrum for the 2-line ferrihydrite (Figure 6a) was consistent with previously reported ones (Murad and Schwertmann 1980). Striking are the differences between the biomineralization products. When ferrihydrite was at great excess $(0.5 \mathrm{mmol} / \mathrm{L}$ lactate $/ 150 \mathrm{mmol} / \mathrm{L}$ ferrihydrite, Figure $6 \mathrm{~b})$, it was transformed to a complex mixture of $\mathrm{Fe}(\mathrm{III})$ oxides including hematite, goethite, lepidocrocite, and more crystalline ferrihydrite. Well-formed crystalline Fe(III)-oxide phases, hematite and goethite, were the dominant biotransformation phases on a mass basis. At a lower electron donor to acceptor ratio $(0.5 \mathrm{mmol} / \mathrm{L}$ lactate $/ 50 \mathrm{mmol} / \mathrm{L}$ ferrihydrite $)$, the oxide was transformed to a mixture of at least two components as inferred by room temperature Mössbauer spectroscopy (Figure 6c), a magnetically ordered phase with an incipient sextet, and a paramagnetic doublet phase. These components were further resolved by study at $77^{\circ} \mathrm{K}$ (Figure $6 \mathrm{~d}$ ) into a mixture of small particle-size goethite and lepidocrocite. Small particle goethite was the mass dominant phase. Finally, when the electron donor was in excess (Figure 6e), the 2-line ferrihydrite was almost fully transformed to fine-grained magnetite, with a small residual concentration of 6-line ferrihydrite (relaxed component).

The Mössbauer spectrum of biogenic magnetite (Figure 6e) and the modeling of the potentially present phases and their distribution involves complexity that deserves comment. The high center background in the Mössbauer spectrum may result from a size effect of nm-sized magnetite particles that can induce "collapse" of the spectrum (McNab et al. 1968) or from the presence of another iron phase that could include maghemite or a more crystalline form of ferrihydrite (e.g., 6-line). The Voight-based modeling technique that was used to simulate the spectra in Figure 6 involves the application of as many as 30 different parameters, and, consequently, there is rarely a unique fit of any given Mössbauer spectrum (e.g., alternate models may give the same sum of squares). We have elected to describe the high baseline effect as resulting from the contribution of a 6-line ferrihydrite phase (relaxed component in Figure 6e) because the resulting lorentzian line widths for the simulated magnetite phase were more realistic. The mineralogic implication of this fit is that DMRB activity may induce crystallization of 2-line ferrihydrite to 6-line ferrihydrite. Further studies, including temperature variant Mössbauer measurements are needed, however, for validation.

The results in Figure 6 demonstrate that iron-reducing bacteria may promote the transformation of poorly crystalline Fe(III) oxides to crystalline ones (hematite, goethite, and lepidocrocite) as well as to ferrous-containing crystalline phases (magnetite). These mineral transformations are believed to result from the reaction of biogenic $\mathrm{Fe}_{(\mathrm{aq})}^{2+}$ with the residual ferrihydrite; however, cysteine, a sulfur containing amino-acid, has also been observed to induce the recrystallization of ferrihydrite to goethite (Cornell and Schneider 1989). When the electron donor is at low concentration relative to the Fe(III) oxide, small amounts of $\mathrm{Fe}_{(\mathrm{aq})}^{2+}$ are released through the reductive process that strongly sorb to the residual oxide at circumneutral $\mathrm{pH}$ (see $\mathrm{Fe}_{(\mathrm{aq})}^{2+}$ sorption data in Fredrickson et al. 1998). Low concentrations of sorbed $\mathrm{Fe}^{2+}$ have been observed to catalytically promote the recrystallization of poorly crystalline Fe(III) oxides to thermodynamically more stable goethite (Fischer 1972), possibly through reductive dissolution (Cornell and Schwertmann 1996). Our observations above indicate that hematite and lepidocrocite, which are also more thermodynamically stable than 2-line ferrihydrite but crystallize by different mechanisms, may also result as products from this process. The differences in mineralization products between the $0.5 \mathrm{mmol} / \mathrm{L} \mathrm{lactate} / 150 \mathrm{mmol} / \mathrm{L}$ ferrihydrite and $0.5 \mathrm{mmol} / \mathrm{L}$ lactate $/ 50 \mathrm{mmol} / \mathrm{L}$ ferrihydrite are not easily explained and imply that the adsorption density of biogenic $\mathrm{Fe}^{2+}$ and the kinetic rate of supply may influence the crystalline structure and particle size of the resulting $\mathrm{Fe}(\mathrm{III})$ oxide. Finally, when the electron donor is in excess, higher levels of biogenic $\mathrm{Fe}^{2+}$ 
are generated that saturate the ferrihydrite surface inducing conversion to magnetite $\left(\mathrm{Fe}_{3} \mathrm{O}_{4}\right.$; Ardizzone and Formaro 1983; Mann et al. 1989).

\section{Influence of Foreign Ions}

In the preceding section it was shown that thermodynamically favored crystalline Fe(III) oxides may result from the action of DMRB on poorly crystalline Fe(III) oxides. Those experiments (Figure 6) utilized synthetic 2-line ferrihydrites free of impurities. In natural environments, however, ferrihydrites may contain coprecipitated trace metals and/or phosphate and silica (Carlson and Schwertmann 1981; Fox 1989; Fortin et al. 1993), and/or coreacted organic materials (Perret et al. 2000). These impurities generally act to stabilize ferrihydrites in natural environments, preventing their long-term recrystallization to more stable goethite and hematite.

Shown in Figure 7 are room-temperature Mössbauer spectra for aged, 2-line ferrihydrite and aged 2-line ferrihydrites substituted with either $5 \mathrm{~mol} \% \mathrm{Ni}$ (II) or $\mathrm{Co}$ (II) (Zachara et al. 2001). The unreduced, aged 2-line ferrihydrite contains microcrystalline goethite as an aging/transformation product (Figure 7a), while coprecipitated $\mathrm{Ni}$ (II) and $\mathrm{Co}$ (II) prevents ferrihydrite recrystallization (Figure $7 \mathrm{c}, \mathrm{e}$ ). The mineralogic products resulting from the activity of DMRB ( $S$. putrefaciens, CN32) on these poorly crystalline Fe(III) oxides varies dramatically (Figure $7 \mathrm{~b}, \mathrm{~d}$, and $\mathrm{f}$ ). These experiments were performed with excess electron donor, for example, $30 \mathrm{mmol} / \mathrm{L}$ lactate and $50 \mathrm{mmol} / \mathrm{L}$ ferrihydrite in $\mathrm{pH} 7$ PIPES buffer. The dominant bioreduction product of the aged 2-line ferrihydrite was finegrained goethite (Figure $7 \mathrm{~b}$ ) in combination with a small amount of magnetite. The Ni(II)substituted ferrihydrite resisted bacterial reduction (Figure 7d). Co(II)-ferrihydrite was biotransformed to a nonstoichiometric magnetite (Figure 7f) in mixture with Co-substituted 2- and 6-line ferrihydrite. Nonstoichiometry was implied by the larger tetrahedral peak height of magnetite that indicated either partial oxidation or Co(II) substitution.

Coreacted ions that retard ferrihydrite crystallization apparently have different effects on ferrihydrite bioavailability to DMRB and the nature of the resulting mineralization products. Both $\mathrm{Co}(\mathrm{II})$ and $\mathrm{Ni}(\mathrm{II})$ prevented the crystallization of goethite during both the aging process and during bioreduction (Figure 7). $\mathrm{Co}$ (II) promoted the transformation to magnetite. $\mathrm{Ni}$ (II), in contrast, prevented the use of ferrihydrite as an electron acceptor. This latter effect appeared to be a mineral/chemical one in that $\mathrm{Ni}$ (II) did not induce adverse physiologic effects on CN32 (Fredrickson et al. 2001). These striking differences may result from the contrasting electronic properties of $\mathrm{Ni}(\mathrm{II})$ and $\mathrm{Co}(\mathrm{II} / \mathrm{III})$. The half-cell potential of the $\mathrm{Co}(\mathrm{II}) / \mathrm{Co}(\mathrm{III})$ couple $(1.48 \mathrm{~V})$ is well above that of $\mathrm{Fe}(\mathrm{II} / \mathrm{III})(0.67 \mathrm{~V}$; Zachara et al. 2001), and the polyvalent character of Co and its redox potential may facilitate electron transfer into ferrihydrite aggregates. Redox inert $\mathrm{Ni}$ (II) apparently blocks electron transduction to and within the ferrihydrite structure.

Sorbed anions including $\mathrm{PO}_{4}^{3-}$ and $\mathrm{H}_{4} \mathrm{SiO}_{4}$ also inhibit ferrihydrite crystallization to goethite and hematite (Carlson and Schwertmann 1981; Cornell et al. 1987; Reeves and Mann 1991; Galvez et al. 1999). This effect results from strong oxyanion surface complexation to, or coprecipitation with, ferrihydrite that may block structural ordering. In spite of the inhibitory effect of $\mathrm{PO}_{4}^{3-}$ on both ferrihydrite crystallization and magnetite formation, its presence as a nutrient at surface saturating concentrations did not appreciably slow or accelerate the bioreduction rate of ferrihydrite at a $\mathrm{P} / \mathrm{Fe}$ ratio of 0.088 (Fredrickson et al. 1998). Sorbed, redox-inert $\mathrm{PO}_{4}^{3-}$ does not block electron transduction to the solid as observed for $\mathrm{Ni}$ (II). Rather, it appears to enhance the extent of bioreduction by removal of potentially passivating byproducts, such as $\mathrm{Fe}(\mathrm{II})$ through vivianite precipitation.

Given the observed importance of sorbed $\mathrm{Si}$ in stabilizing ferrihydrites in terrestrial environments, a Si-containing ( $2 \mathrm{~mol} \%)$, 2-line ferrihydrite was synthesized by coprecipitation 

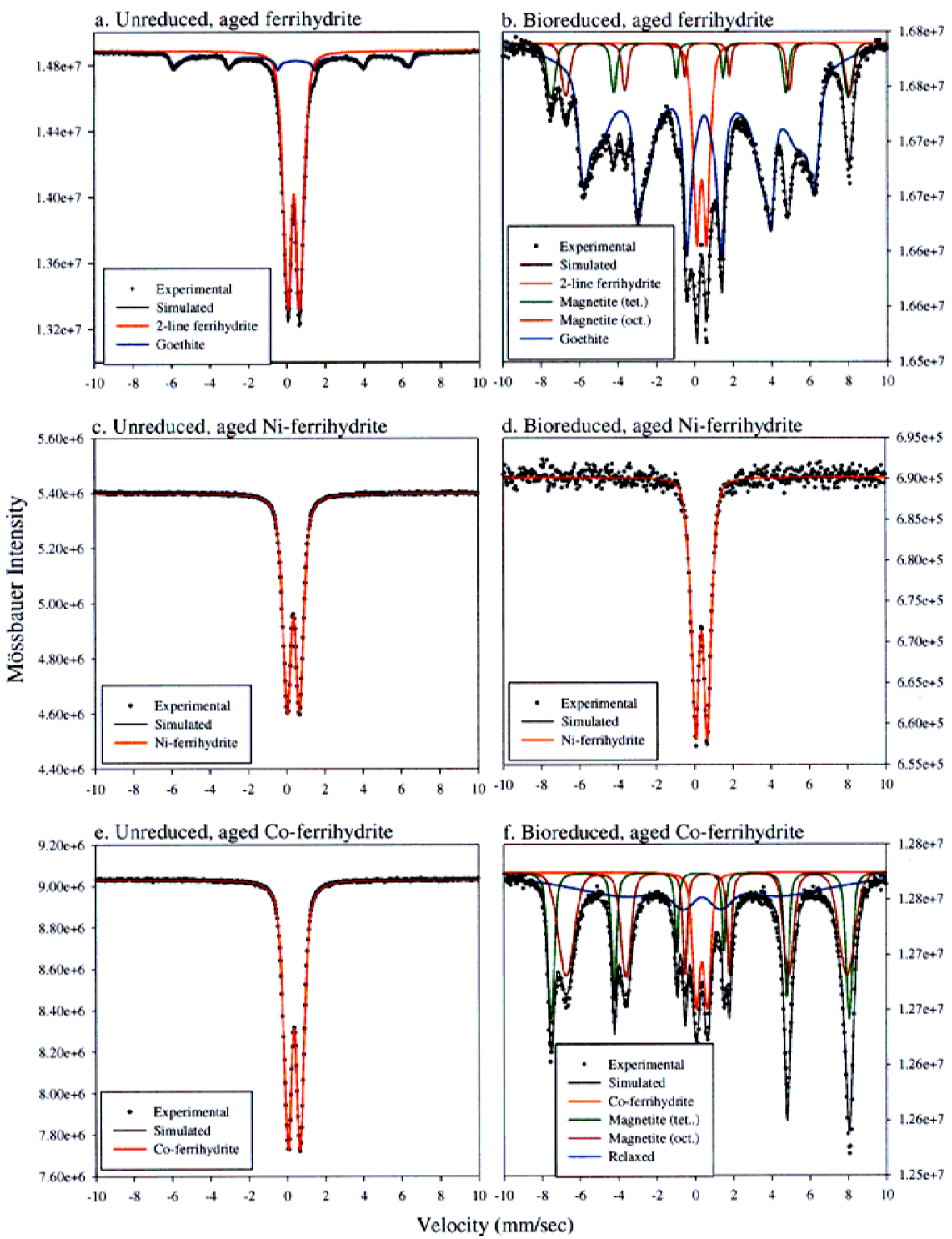

FIGURE 7 Room temperature Mössbauer spectra of unreduced and bioreduced, (a) and (b) aged ferrihydrite, (c) and (d) Ni-spiked ferrihydrite, and (e) and (f) Co-spiked ferrihydrite. The bioreduction experiments were performed in PIPES buffer. Voight-based model simulations are shown by solid line along with contributing mineral phases. Mag(TET) and $\operatorname{Mag}(\mathrm{OCT})$ refer to the tetrahedral and octahedral sites of magnetite.

to evaluate its behavior under Fe(III)-reducing conditions promoted by DMRB. The anoxic incubation with CN32 was performed identically to those reported in Figure $7(50 \mathrm{mmol} / \mathrm{L}$ 2-line ferrihydrite, $30 \mathrm{mmol} / \mathrm{L}$ lactate, $\mathrm{pH} 7 \mathrm{PIPES}$ buffer, and no $\mathrm{PO}_{4}^{3-}$ ), and samples of the residual oxide were subsampled after 1, 8, and $28 \mathrm{~d}$ of incubation. The XRD and Mössbauer spectra of the starting Si-ferrihydrite were identical to pure ferrihydrite (not shown, e.g., Figure 6a). XRD and Mössbauer analyses of the bioreduced solids indicated rapid conversion of Si-containing ferrihydrite to fine-grained magnetite within 1 day of incubation with DMRB (Figure 8). Greenalite, a ferrous silicate, was not observed in any of the bioreduced 

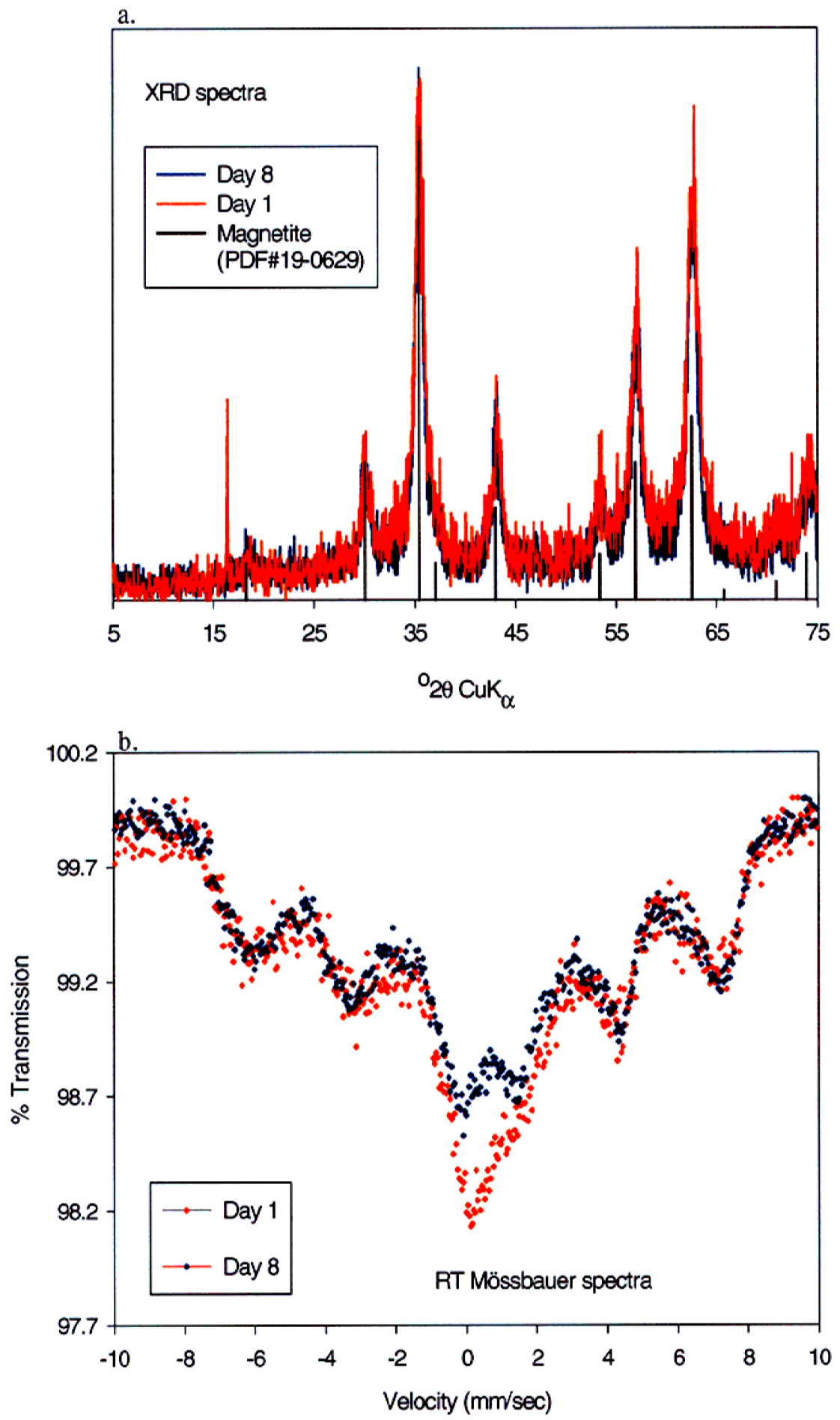

FIGURE 8 X-ray diffraction (a) and room temperature Mössbauer spectra (b) of bioreduced 2-line ferrihydrite containing $2 \mathrm{~mol} \% \mathrm{Si}$. Shown are samples collected after 1 and 8 days of incubation of $50 \mathrm{mmol} / \mathrm{L}$ ferrihydrite with CN32 in $\mathrm{pH} 7$ PIPES buffer with $30 \mathrm{mmol} / \mathrm{L}$ lactate. 
samples. The 1-day sample contained some residual ferrihydrite (singlet at approximately $0 \mathrm{~mm} / \mathrm{sec}$ ) that was further reduced between days 1 and 8 . The fine-grained character of the magnetite $(<10 \mathrm{~nm})$ was indicated by the collapsed nature of the Mössbauer spectra (Figure 8a; compare Figure 8a to Figure 6c). The rapid conversion of the Si-ferrihydrite to magnetite indicates that, unlike $\mathrm{PO}_{4}^{3-}, \mathrm{H}_{4} \mathrm{SiO}_{4}$ does not inhibit magnetite formation. Moreover, the presence of sorbed/coprecipitated $\mathrm{H}_{4} \mathrm{SiO}_{4}$ at the concentration studied had no inhibitory effect on ferrihydrite reduction, and it may, in fact, have stimulated the rate of ferrihydrite conversion. These results markedly contrast with the inhibitatory effect of $\mathrm{H}_{4} \mathrm{SiO}_{4}$ on ferrihydrite crystallization to goethite and hematite under oxidizing conditions. These four examples indicate that it is not currently possible to generalize on the effects of coreacted ions on ferrihydrite bioreducibility and mineral transformation.

\section{Bioreduction in Mixtures of Fe(III) Oxides}

$\mathrm{Fe}(\mathrm{III})$ oxides in soils, subsurface sediments, and geologic materials often exist as phase mixtures of poorly crystalline and crystalline phases (e.g., Bigham et al. 1991). Such mixtures result from the metastable/transitory nature of ferrihydrite with respect to goethite and hematite. Over time, ferrihydrite will transform to thermodynamically more stable hematite and goethite, even if stabilized by adsorbed/coprecipitated impurities. The transition is controlled by a variety of environmental factors including $\mathrm{pH}$, temperature, organic matter content, and possible microbiologic effects (Cornell and Schwertmann 1996).

Whereas the crystalline Fe(III) oxides are bioreducible to a degree by DMRB (Roden and Zachara 1996; Zachara et al. 1998; Kukkadapu et al. 2001), the poorly crystalline Fe(III) oxides are more bioavailable (Lovely and Phillips 1986, 1987). The enhanced bioavailability of ferrihydrite over the crystalline oxides is clearly shown in Figure 9 where a mixture of hematite, goethite, and 2-line ferrihydrite $(50 \mathrm{mmol} / \mathrm{L}$ total $\mathrm{Fe})$ was subject to reduction by $S$. putrefaciens $\left(10^{8}\right.$ cells $/ \mathrm{mL}$ of $\left.\mathrm{CN} 32\right)$ under anoxic conditions in PIPES buffer with excess electron donor $(30 \mathrm{mmol} / \mathrm{L}$ lactate). In Figure $9 \mathrm{a}$, the three starting oxides are clearly differentiated by transmission Mössbauer spectroscopy. This mixture was obtained by heating 2-line ferrihydrite for $10 \mathrm{~d}$ at $70^{\circ} \mathrm{C}$. After $32 \mathrm{~d}$ incubation, the Mössbauer doublet associated with 2-line ferrihydrite has been removed by bioreduction, and the goethite sextet strengthened relative to hematite (Figure 9b). Our results cannot resolve whether the enhanced goethite Mössbauer signal (Figure 9b) resulted from additional goethite formation during incubation or from the partial bioreduction of hematite relative to goethite.

Unlike the results for $30 \mathrm{mmol} / \mathrm{L}$ lactate and $50 \mathrm{mmol} / \mathrm{L}$ 2-line ferrihydrite in Figure 6e where magnetite was formed, no Fe(II)-containing mineral products were produced in the experiment shown in Figure 9. In contrast, the Fe(II) was evolved to the aqueous phase where it sorbed to the residual goethite and hematite surfaces. At experiment termination, $8 \mathrm{mmol} / \mathrm{L}$ of $\mathrm{Fe}(\mathrm{III})$ had been reduced and, of this, $5 \mathrm{mmol} / \mathrm{L}$ was present in the aqueous phase and $3 \mathrm{mmol} / \mathrm{L}$ was sorbed to the crystalline Fe(III) oxides. While the observations imply that crystalline $\mathrm{Fe}$ (III) oxides may impede biomineralization of 2-line ferrihydrite by sorption of biogenic Fe(II), we note that small amounts of 2-line ferrihydrite (e.g., 5-10 mmol/L with $30 \mathrm{mmol} / \mathrm{L}$ lactate) are also fully solubilized by CN32 when crystalline $\mathrm{Fe}(\mathrm{III})$ oxides are not present. This solubilization may be facilitated by the excess concentration of lactate, which is a weak complexant of $\mathrm{Fe}_{(\mathrm{aq})}^{2+}$.

\section{A Conceptual Model Based on Laboratory Studies}

The laboratory biomineralization studies of 2-line ferrihydrite reported to date support a conceptual model where the rate of supply and total concentration of biogenic $\mathrm{Fe}$ (II) is the primary determinant of the nature of secondary mineralization products (Figure 10). 


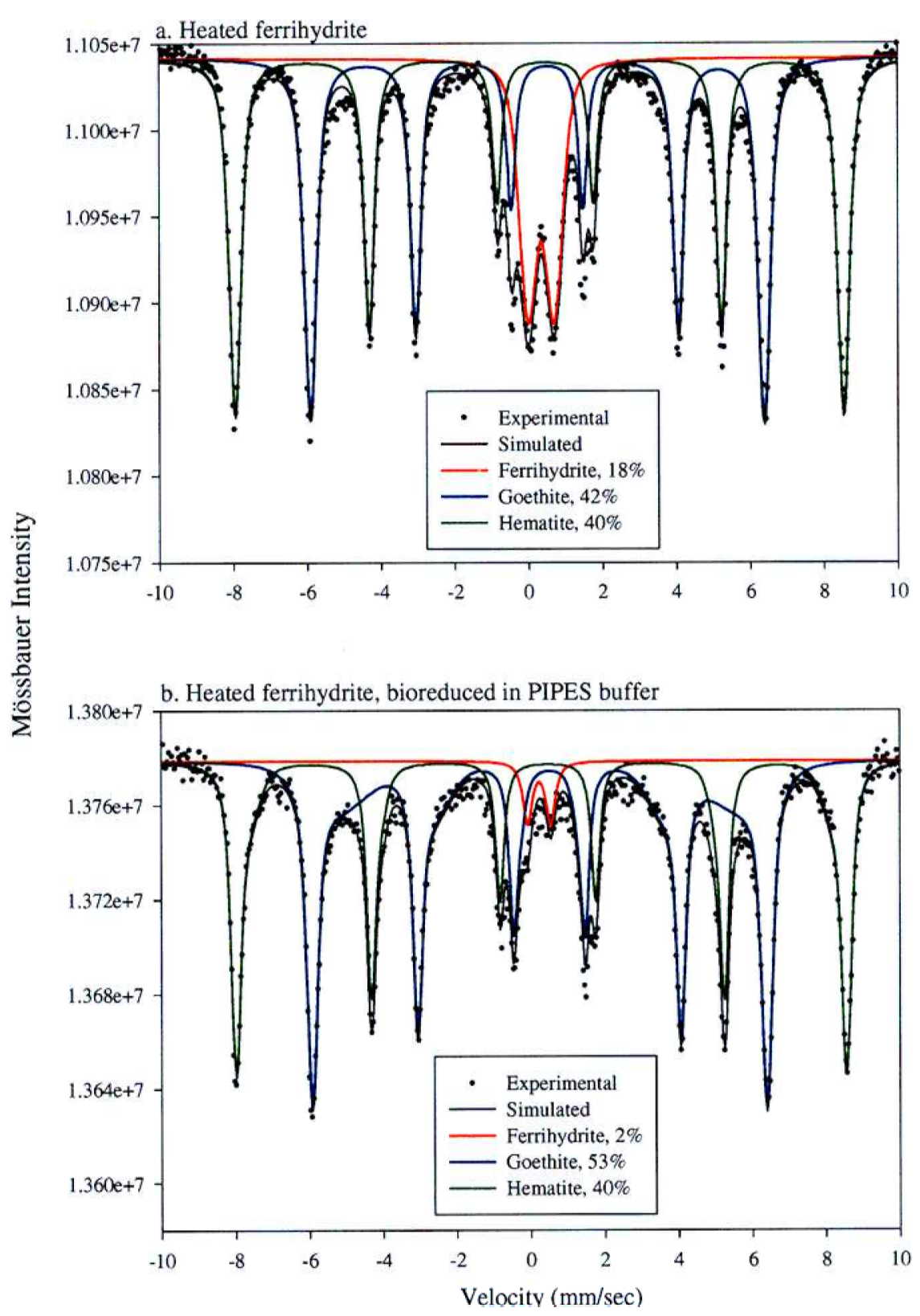

FIGURE 9 Room temperature (RT) Mössbauer spectrum of 2-line ferrihydrite that had been heated at $70^{\circ} \mathrm{C}$ for $10 \mathrm{~h}$, (a) showing presence of ferrihydrite, goethite, and hematite. RT Mössbauer spectrum of bioreduced, heated 2-line ferrihydrite $(50 \mathrm{mmol} / \mathrm{L}$ initial $)$ with excess electron donor (30 mmol/L), (b) showing loss of ferrihydrite peak. Voight-based model simulations are shown by solid line along with contributing mineral phases. Mass percentages calculated from spectral areas. 


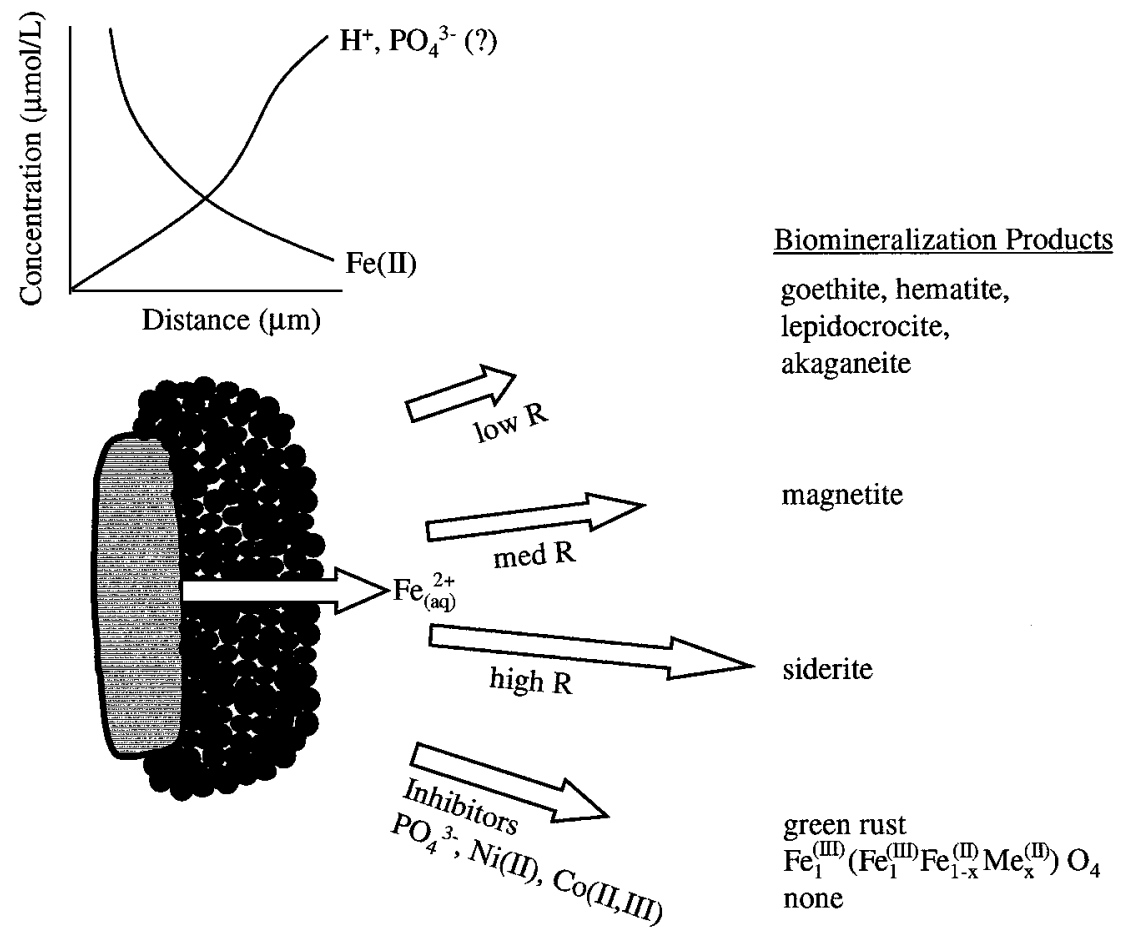

Microenvironment Effects

$\mathrm{Fe}(\mathrm{OH})_{3}+1 / 4 \mathrm{CH}_{3} \mathrm{CHOHCOO}+1^{3 / 4} \mathrm{H}^{+}=\mathrm{Fe}^{2+}+1 / 4 \mathrm{CH}_{3} \mathrm{COO}^{-}+1 / 4 \mathrm{HCO}_{3}{ }^{-}+2^{1 / 2} \mathrm{H}_{2} \mathrm{O} \Delta \mathrm{G}_{\mathrm{r}}{ }^{\circ}$

FIGURE 10 Conceptual model of ferrihydrite biomineralization showing aggregated ferrihydrite nanoparticles around the DMRB and vectors to represent the magnitude and rate of biogenic Fe(II) flux (R). A gradient of $\mathrm{Fe}(\mathrm{II}), \mathrm{OH}^{-}$, coreacted ions, and electron donor oxidation products is assumed to exist from the organism surface out to the bulk media.

Electron microscopy of ferrihydrite/DMRB suspensions indicates that nm-sized ferrihydrite particles aggregate and cluster around DMRB cells at circumneutral $\mathrm{pH}$ (Y. Gorby, unpublished data). This bacterial aggregation is visibly obvious and leads to the flocculation of the ferrihydrite suspension.

The cellular oxidation of the electron donor generates an electron flux into the aggregated ferrihydrite, presumably at or near the organism interface. It is important to note that very little is known about the biochemical aspects of these systems, particularly with regard to the mechanisms by which $\mathrm{Fe}$ (III) is reduced at the membrane-oxide interface. The intracellular respiration reaction combined with electron transfer generates a gradient (a microenvironment) of $\mathrm{Fe}$ (III) oxide dissolution products [ $\mathrm{Fe}(\mathrm{II}), \mathrm{OH}$; or $\mathrm{PO}_{4}^{3-} / \mathrm{H}_{4} \mathrm{SiO}_{4}$ or trace metals if adsorbed or coprecipitated with ferrihydrite] and electron donor oxidation products (e.g., acetate and bicarbonate from lactate) that diffuse outward through the aggregated ferrihydrite. The reaction products [e.g., $\mathrm{Fe}(\mathrm{II}), \mathrm{HCO}_{3}^{-}$] may form aqueous complexes, adsorb/complex to the residual oxide or cell surface and promote mineral transformation, or react in some other manner. The circumneutral $\mathrm{pH}$ conditions typically used for these bioreduction studies favor the strong sorption of $\mathrm{Fe}(\mathrm{II}), \mathrm{PO}_{4}^{3-}, \mathrm{H}_{4} \mathrm{SiO}_{4}$, and $\mathrm{HCO}_{3}^{-}$by the residual ferrihydrite surface (Fredrickson et al. 1998, 2001; Zachara et al. 1998). The hydrogen ion activity may be significantly lower in the aggregated ferrihydrite microenvironment than in the bulk media as a result of $\mathrm{Fe}(\mathrm{III})$ oxide dissolution (reactions 1 and 2). The higher $\mathrm{pH}$ of the microenvironment is conducive to recrystallization of Fe(III) 
oxides (Schwertmann and Murad 1983; Cornell and Schwertmann 1996) and the formation of ferrous iron solids.

The formation of crystalline Fe(III) oxides occurs when the reduction rate is slow, and the sorption density of Fe(II) is low on the residual ferrihydrite. This Fe(II) catalyzed abiotic reaction is very sensitive to $\mathrm{pH}$ and $\mathrm{Fe}$ (II) concentration (Fischer 1972) with maximum rates occurring near $\mathrm{pH}$ 6.5. Magnetite appears as the primary biomineralization product when the reduction rate increases and more $\mathrm{Fe}(\mathrm{II})$ is produced. This observation may also be explained on abiotic grounds (Ardizzone and Fomaro 1983; Mann et al. 1989). Magnetite formation is promoted by sorptive surface saturation of the ferrihydrite. Perhaps the crystallization vectors of goethite/hematite and magnetite are competitive. Siderite formation is encouraged by rapid reduction rates and $\mathrm{mmol} / \mathrm{L}$ concentrations of bicarbonate that function as ligands for the solid phase and, possibly, inhibitors of magnetite formation.

The role of biosorption and the cell surface on the reductive phase transformations of ferrihydrite are unclear. Although it is known that $\mathrm{Fe}^{2+}$ sorbs significantly to the DMRB surface (Urrutia et al. 1998; Liu et al. 2001b), it is not known whether this sorption is instrumental in the nucleation of secondary phases. Electron microscopy has yet to show phase morphologies consistent with a direct microbial role in the precipitation of siderite, vivianite, green rust, or the crystalline Fe(III) oxides; although studies of sufficient detail have not been performed.

The formation of hematite, goethite, and magnetite sequesters residual Fe(III) in mineralogic environments that are less bioavailable than ferrihydrite. This reduction in bioavailability reflects differences in the free energies of the newly formed phases in relation to the electron donor, as well as the crystalline structure of the Fe(III)-containing phases and its effect on reductive dissolution rates as compared to ferrihydrite. These transformations act to slow or terminate further bioreduction even if excess electron donor is present.

Spatial and temporal chemical heterogeneity are two potential explanations for the common observation of mixtures of biomineralization products (e.g., goethite with siderite and/or magnetite) that are in global disequilibrium (Figures 4 and 7). Local spatial heterogeneity in chemical conditions surrounding respiring DMRB (microenvironments and chemical gradients) may allow the simultaneous precipitation of different mineral phases. In Figure 10, for example, chemical conditions may be conducive to the formation of one mineral phase near the ferrihydrite/DMRB interface, and another phase near the ferrihydrite/bulk solution interface as a result of a concentration gradient in $\mathrm{Fe}$ (II) and $\mathrm{OH}^{-}$. Alternatively, temporally evolving chemical conditions as electron equivalents are liberated from the electron donor by respiration may create a reaction path that traverses Eh-pH space (e.g., Figure 2). Biomineralization phases that precipitate early in the incubation, but that are slowly reactive once formed (e.g., hematite, goethite, and magnetite), may be a relict of the reaction path and indicative of previous conditions.

The effect of coreacted ions on the bioreductive phase transformation of ferrihydrite is not easily generalized because of insufficient research and highly variable chemical behavior. The influence of adsorbed anions and cations on the abiotic transformation of 2-line ferrihydrite to crystalline Fe(III) oxides has been summarized by Cornell and Schwertmann (1996). Under reducing conditions promoted by DMRB, the coreacted ions may be solubilized, they may engage in solid-state reaction with biogenic $\mathrm{Fe}$ (II)[e.g., $\mathrm{PO}_{4}^{3-}$ to form vivianite or $\mathrm{H}_{4} \mathrm{SiO}_{4}$ to form greenalite $\left(\mathrm{Fe}_{3} \mathrm{Si}_{2} \mathrm{O}_{5}(\mathrm{OH})_{4}\right)$ ], or they may coprecipitate in biogenic secondary phases (e.g., $\mathrm{Co}$ (II) or $\mathrm{Ni}$ (II) with vivianite, siderite, magnetite, or green rust; Fredrickson et al. 2001; Parmar et al. 2001; Zachara et al. 2001). Solubilized ligands (e.g., $\mathrm{PO}_{4}^{3-}$ or organic material) may complex $\mathrm{Fe}(\mathrm{II})$, lowering solution phase activities and mineral phase supersaturation, or may react with growth sites on nucleating biomineral surfaces influencing their precipitation kinetics. For these reasons, coreacted ions may have 
important kinetic effects by either stimulating (e.g., Co) or retarding (e.g., Ni) biomineralization, or promoting the formation of different phases (e.g., $\mathrm{PO}_{4}^{3-}$ /vivianite or green rust) through inhibition or mass action effects. Water advection (Roden and Urrutia 1999; Roden et al. 2000) or associated sorbing mineral phases (e.g., Kukkadapu et al. 2001) as exist in sediment or soil may also influence the biomineralization process by removing $\mathrm{Fe}$ (II) from the bulk fluid phase and steepening the diffusional gradient within the DMRB-ferrihydrite aggregate (Figure 10). These effects, like that of aqueous complexation, may suppress biomineralization by preventing requisite degrees of supersaturation of $\mathrm{Fe}(\mathrm{II})$-containing phases.

The conceptual model in Figure 10 is most relevant to suspensions of synthetic finegrained ferrihydrite as investigated in this study. The physical model may differ appreciably in soils or subsurface sediments where ferrihydrite microprecipitates exist in close association with surfaces that have functioned as precipitation templates or Fe sources, or in freshwater sediments where ferrihydrite flocs of complex and varied morphology may form containing bacterial remains and organic matter (e.g., Fortin et al. 1993; Perret et al. 2000). In each of these environments ferrihydrite is often found in association with, and physically bound to, more crystalline Fe(III) oxides including lepidocrocite and goethite. Under these natural conditions, a different but as yet unspecified physical model may be more appropriate than the particle collection model in Figure 10. Little published information exists on the reductive biomineralization of ferrihydrite in soils, subsurface sediments, and/or natural waters upon which to base a more relevant conceptual model for the DMRB-ferrihydrite interaction and the relationships to biomineralization. This information lack stems in part from the typically low concentration of poorly crystalline $\mathrm{Fe}(\mathrm{III})$ oxides in natural materials and the attendant analytical difficulties surrounding their isolation and rigorous analysis.

\section{Summary and Research Opportunities}

The biotransformation of 2-line ferrihydrite by DMRB is a complex processes that, in spite of the work presented above, is not well understood. The primary driving force for biotransformation is the thermodynamic instability of 2-line ferrihydrite under both oxidizing and reducing conditions. Different phases may result depending on electron donor to acceptor ratio, solution conditions, coreacted ions, and other factors that define kinetic pathways and thermodynamic end states. The biomineralization process appears to be an indirect one, where biogenic $\mathrm{Fe}$ (II) catalyzes the transformation through its surface reaction (surface complexation, electron transfer) with the residual 2-line ferrihydrite and other cosorbed ions (e.g., $\mathrm{PO}_{4}^{3-}, \mathrm{HCO}_{3}^{-}$). The nature of biomineralization products produced are sensitive to the total concentration and rate of supply of $\mathrm{Fe}$ (II), and $\mathrm{pH}$ as influenced by $\mathrm{Fe}$ (III) oxide dissolution. Similar mineralogic products have been observed in abiotic analogue studies, where $\mathrm{Fe}(\mathrm{II})$ has been added to ferrihydrite suspensions.

This analysis concludes that a complex combination of thermodynamic and kinetic factors control whether a single, thermodynamically stable solid or a nonequilibrium phase mixture are the final products. Under certain conditions (e.g., high and low electron donor) the biomineralization products are predictable and conform to the most thermodynamically stable solid. In other cases, phase mixtures result from microenvironment or reaction path effects, or poorly resolved competitive kinetic pathways. Current knowledge is generally insufficient to predict which phase or assemblage will result under specific chemical conditions or ratios of electron donor to acceptor.

Fruitful research opportunities exist in all topical areas covered by this publication. Greater research attention is needed in DMRB biomineralization studies to the mineralogic nature of the starting $\mathrm{Fe}(\mathrm{III})$ oxide phase, its mineralogic state during the course 
of bioreduction, and the solution chemical changes that accompany the biomineralization process, including chemical dynamics near the cell. Moreover, the biology of the DMRB system has also not been well studied, in particular with regard to the precise electron transfer mechanism and physiologic changes that may occur to the DMRB as the speciation and reactivity of Fe evolves.

This study has focused on laboratory studies of the DMRB transformation of synthetic 2-line ferrihydrite both without and with a number of coreacted inorganic ions. Unevaluated were the effects of bacterial remains and organic matter, which seem to be important components of natural ferrihydrites. Also unstudied where the effects of electrolyte (e.g., $\mathrm{Cl}^{-}$versus $\mathrm{NO}_{3}^{-}$) and preparation method (e.g., hydrolysis versus oxidation) on the phase transformations of 2-line ferrihydrite, but these are not expected to be significant. Surprisingly, few comparable studies exist on the biotransformation of 6-line ferrihydrite, or of poorly crystalline Fe(III) oxides in soils or subsurface environments, or in the field setting. Although it is expected that the reactions and phenomenology reported herein with synthetic $\mathrm{Fe}(\mathrm{III})$ oxides and single culture DMRB will and do occur in the environment, there may be significant differences that result from the complex nature of natural Fe(III) oxides (of both abiotic and microbiologic origin), the nature and rate of supply of electron donors, the presence of mixed bacterial populations, and the occurrence of accessory mineral phases to act as precipitation templates and adsorption repositories. Significant differences may exist in the bioreduction kinetics of poorly crystalline Fe(III) oxides from soil/geologic and aquatic environments as a result of morphologic and compositional differences. Studies on the reductive biomineralization of poorly crystalline Fe(III) oxides by DMRB in natural materials and in the field are critically needed, as are those on the reactivity and fate of these products when oxidizing conditions return.

\section{References}

Al-Borno A, Tomson MB. 1994. The temperature dependence of the solubility product constant of vivianite. Geochim Cosmochim Acta 58:5373-5378.

Ardizzone S, Formaro L. 1983. Temperature induced phase transformation of metastable $\mathrm{Fe}(\mathrm{OH})_{3}$ in the presence of ferrous ions. Mat Chem Phys 8:125-133.

Bigham JM, Heckendorn SE, Jaynes WF, Smeck NE. 1991. Stability of iron oxides in two soils with contrasting colors. Soil Sci Soc Am J. 55:1485-1492.

Campbell AS, Schwertmann U. 1984. Iron oxide mineralogy of placic horizons. J Soil Sci 35:556-582.

Campbell AS, Schwertmann U. 1985. Evaluation of selective dissolution extractants in soil chemistry and mineralogy by differential X-ray diffraction. Clay Min 20:515-519.

Carlson L, Schwertmann U. 1981. Natural ferrihydrites in surface deposits from Finland and their association with silica. Geochim Cosmochim Acta 45:421-429.

Childs CW. 1992. Ferrihydrite: a review of structure, properties, and occurrence in relation to soils. Z Pfanzenernbhr Bndenk 155:441-448.

Chukhrov FV, Zvyagin BB, Gorshkov AI, Ermilova LP, Balashova VV. 1973. Ferrihydrite. Izvest Akad Nauk SSSR Ser Geol 4:23-33.

Cornell RM, Giovanoli R, Schindler PW. 1987. Effect of silicate species on the transformation of ferrihydrite into goethite and hematite in alkaline media. Clays Clay Miner 35:21-28.

Cornell RM, Schneider W. 1989. Formation of goethite from ferrihydrite at physiological pH under the influence of cysteine. Polyhedron 8:424-432.

Cornell RM, Schwertmann U. 1991. Iron oxides in the laboratory: preparation and characterization. VCH Weinheim, Federal Republic of Germany. 137 p.

Cornell RM, Schwertmann U. 1996. The Fe oxides: structure, properties, reactions, occurrences, and uses. VCH Weinheim, Federal Republic of Germany. 573 p.

Couling SB, Mann S. 1985. The influence of inorganic phosphate on the crystallization of magnetite $\left(\mathrm{Fe}_{3} \mathrm{O}_{4}\right)$ from aqueous solution. J Chem Soc Chem Comm 1713-1715. 
Dong H, Fredrickson JK, Kennedy DW, Zachara JM, Kukkadapu RK, Onstott TC. 2000. Mineral transformation associated with the microbial reduction of magnetite. Chem Geol 169:299-318.

Drissi SH, Refait PH, Abdelmoula M, Génin JMR. 1995. The preparation and thermodynamic properties of $\mathrm{Fe}(\mathrm{II})-\mathrm{Fe}(\mathrm{III})$ hydroxide-carbonate (green rust 1); Pourbaix diagram of iron in carbonatecontaining aqueous media. Corr Sci 37(12):2025-2041.

Dzombak DA, Morel FMM. 1990. Surface complexation modeling: hydrous ferric oxide. New York: Wiley. $393 \mathrm{p}$.

Feitknecht W, Giovanoli R, Michaelis W, Muller M. 1973. Uber die hydrolyse von eisen(III) salzlosungen. I. Die hydrolyse der losungen von eisen(III) chlorid. Helv Chim Acta 56:2847-2856.

Fischer WR. 1972. Die wirkung von zweiwertigem eisen auf losung und umwandlung von eisen(III)hydroxiden. In: Schlichting E, Schwertmann U, editors. Pseudogley and gley. Trans Comm V and VI Int Soil Sci Soc, Weinheim: VCH, p 37-44.

Ford RG, Bertsch PM, Farley KJ. 1997. Changes in transition and heavy metal partitioning during hydrous iron oxide aging. Environ Sci Technol 31:2028-2033.

Fortin D, Leppard GG, Tessier A. 1993. Characteristics of lacustrine diagenetic iron oxyhydroxides. Geochim Cosmochim Acta 57:4391-4404.

Fox LE. 1988. The solubility of colloidal ferric hydroxide and its relevance to iron concentrations in river water. Geochim Cosmochim Acta 52:771-777.

Fox LE. 1989. A model for inorganic control of phosphate concentrations in river waters. Geochim Cosmochim Acta 53:417-428.

Fredrickson JK, Zachara JM, Kennedy DW, Li S-M, Hinman NW. 1998. Biogenic iron mineralization accompanying the dissimilatory reduction of hydrous ferric oxide by a groundwater bacterium. Geochim Cosmochim Acta 62:3239-3257.

Fredrickson JK, Zachara JM, Kukkadapu RK, Gorby YA, Smith SC, Brown CF. 2001. Biotransformation of Ni-substituted hydrous ferric oxide by an Fe(III)-reducing bacterium. Environ Sci Technol 35:703-712.

Gálvez N, Barrón V, Torrent J. 1999. Effect of phosphate on the crystallization of hematite, goethite, and lepidocrocite from ferrihydrite. Clays Clay Miner 47(3):304-311.

Garrels RM, Christ CL. 1965. Solutions, minerals, and equilibria. San Francisco: Freeman, Cooper and Company. $450 \mathrm{p}$.

Génin JMR, Bourrie G, Trolard F, Abdelmoula M, Jaffrezic A, Refait PH, Maitre V, Humbert B, Herbillon A. 1998b. Thermodynamic equilibria in aqueous suspensions of synthetic and natural $\mathrm{Fe}(\mathrm{II})-\mathrm{Fe}(\mathrm{III})$ green rusts: occurrences of the mineral in hydromorphic soils. Environ Sci Technol 32:1058-1068.

Génin JMR, Refait PH, Simon L, Drissi SH. 1998a. Preparation and $E_{\mathrm{h}}-\mathrm{pH}$ diagrams of $\mathrm{Fe}(\mathrm{II})-$ $\mathrm{Fe}$ (III) green rust compounds; hyperfine interaction characteristics and stoichiometry of hydroxychloride, -sulphate and -carbonate. Hyperfine Interactions 111:313-318.

Hansen HCB, Poulsen IF. 1999. Interaction of synthetic sulphate "green rust" with phosphate and the crystallization of vivianite. Clays Clay Miner 47(3):312-318.

Kostka JE, Nealson KH. 1995. Dissolution and reduction of magnetite by bacteria. Environ Sci Technol 29:2535-2540.

Kukkadapu RK, Zachara JM, Smith SC, Fredrickson JK, Liu C. 2001. Dissimilatory bacterial reduction of al-substituted goethite in subsurface sediments. Geochim Cosmochim Acta 65:29132924.

Lindsay W. 1979. Chemical equilibria in soils. New York: Wiley. 449 p.

Liu C, Kota S, Zachara JM, Fredrickson JK, Brinkman C. 2001a. Kinetic analysis of the bacterial reduction of goethite. Environ Sci Technol 35:2482-2490.

Liu C, Zachara JM, Gorby YA, Szecsody JE, Brown CF. 2001b. Microbial reduction of Fe(III) and sorption/precipitation of Fe(II) on Shewanella putrefaciens Strain CN32. Environ Sci Technol 35:1385-1393.

Lovely DR. 1991. Magnetite formation during microbial dissimilatory iron reduction. In: Frankel RB, Blakemore RP, editors. Iron biominerals. New York: Plenum Press, p 151-166.

Lovley DR, Phillips EJP. 1986. Availability of ferric iron for microbial reduction in bottom sediments of the freshwater tidal Potomac River. Appl Environ Microbiol 52:751-757. 
Lovley DR, Phillips EJP. 1987. Rapid assay for microbially reducible ferric iron in aquatic sediments. Appl Environ Microbiol 53:1536-1540.

Lovley DR, Phillips EJP, Lonergan DJ. 1991. Enzymatic versus nonenzymatic mechanisms for Fe ${ }^{3+}$ reduction in aquatic sediments. Environ Sci Technol 25:1062-1067.

Lovley DR, Stolz JF, Nord GL, Jr, Phillips EJP. 1987. Anaerobic production of magnetite by a dissimilatory iron-reducing microorganism. Nature 330:252-254.

Manceau A, Drits VA. 1993. Local structure of ferrihydrite and feroxyhite by EXAFS spectroscopy. Clay Miner 28:165-184.

Mann S, Sparks NHC, Couling SB, Larcombe MC, Frankel RB. 1989. Crystallochemical characterization of magnetic spinels prepared from aqueous solution. J Chem Soc Faraday Trans 85:30333044.

McNab TK, Fox RA, Boyle AJF. 1968. Some magnetic properties of magnetite $\left(\mathrm{Fe}_{3} \mathrm{O}_{4}\right)$ microcrystals. J Appl Phys 39:5703-5711.

Mortimer RJG, Coleman ML. 1997. Microbial influence on the isotopic composition of diagentic siderite. Geochim Cosmochim Acta 61:1705-1711.

Mortimer RJG, Coleman ML, Rae JE. 1997. Effect of bacteria on the elemental composition of early diagenetic siderite: implications for palaeoenvironmental interpretations. Sedimentology 44:759-765.

Murad E, Schwertmann U. 1980. The Mössbauer spectrum of ferrihydrite and its relations to those of other iron oxides. Am Mineral 65:1044-1049.

Pankhurst QA, Pollard RJ. 1992. Structural and magnetic properties of ferrihydrite. Clays Clay Miner 40:268-272.

Parmar N, Gorby YA, Beveridge TJ, Ferris FG. 2001. Formation of green rust and immobilization of nickel in response to bacterial reduction of hydrous ferric oxide. Geomicrobiology J 18:375-385.

Perret D, Gaillard J-F, Dominik J, Atteia O. 2000. The diversity of natural hydrous iron oxides. Environ Sci Technol 34:3540-3546.

Phillips EJP, Lovley DR, Roden EE. 1993. Composition of non-microbially reducible $\mathrm{Fe}^{3+}$ in aquatic sediments. Appl Environ Microbiol 59:2727-2729.

Postma D, Jakobsen R. 1996. Redox zonation: equilibrium constraints on the $\mathrm{Fe}(\mathrm{III}) / \mathrm{SO}_{4}$-reduction interface. Geochim Cosmochim Acta 60:3169-3175.

Rancourt DG, Ping JY. 1991. Voigt-based methods for arbitrary-shape static hyperfine parameter distributions in Mössbauer spectroscopy. Nucl Instrum Meth Phys Res B58:85-87.

Reeves NJ, Mann S. 1991. Influence of inorganic and organic additives on the tailored synthesis of iron oxides. J Chem Soc Faraday Trans I 87:3875-3880.

Roden EE, Urrutia MM. 1999. Ferrous iron removal promotes microbial reduction of crystalline iron(III) oxides. Environ Sci Technol 33:1847-1853.

Roden EE, Urrutia MM, Mann CJ. 2000. Bacterial reductive dissolution of crystalline Fe(III) oxide in continuous-flow column reactors. Appl Environ Microbiol 66:1062-1065.

Roden EE, Zachara JM. 1996. Microbial reduction of crystalline iron(III) oxides: influence of oxide surface area and potential for cell growth. Environ Sci Technol 30:1618-1628.

Russell JD. 1979. Infrared spectroscopy of ferrihydrite: evidence for the presence of structural hydroxyl groups. Clay Min 14:109-114.

Schindler P, Michaelis W, Feitknecht W. 1963. Loslichkeitsprodukte von metalloxiden undhydroxiden. 8. Mitt.: die loslichkeit gealterter eisen(III)-hydroxid-fallungen. Helv Chim Acta 46:444-451.

Schwertmann U. 1973. Use of oxalate for Fe extraction from soils. Can J Soil Sci 53:244-246.

Schwertmann U, Cornell RM. 1991. Iron oxides in the laboratory: preparation and characterization. VCH Weinheim, Federal Republic of Germany.

Schwertmann U, Fechter H. 1994. The formation of green rust and its transformation to lepidocrocite. Clay Miner 29:87-92.

Schwertmann U, Murad E. 1983. Effect of $\mathrm{pH}$ on the formation of goethite and hematite from ferrihydrite. Clays Clay Min 31:277-284.

Schwertmann U, Schulze DG, Murad E. 1982. Identification of ferrihydrite in soils by dissolution kinetics, differential X-ray diffraction, and Mössbauer spectroscopy. Soil Sci Soc Am J 46:869874. 
Stanjek H, Weidler PG. 1992. The effect of dry heating on the chemistry, surface area, and oxalate solubility of synthetic 2-line and 6-line ferrihydrites. Clay Miner 27:397-412.

Tessier A, Fortin D, Belzile N, DeVitre RR, Leppard GG. 1996. Metal sorption to diagenetic iron and manganese oxyhydroxides and associated organic matter: narrowing the gap between field and laboratory measurements. Geochim Cosmochim Acta 60:387-404.

Thornber MR, Nickel EH. 1976. Supergene alteration of sulphides. III. The composition of carbonates. Chem Geol 17:45-72.

Towe KM, Bradley WF. 1967. Mineralogical constitution of colloidal "hydrous ferric oxides." J Colloid Interface Sci 24:384-392.

Trolard F, Génin JMR, Abdelmoula M, Bourrie G, Humbert B, Herbillon A. 1997. Identification of a green rust mineral in a redoctomorphic soil by Mössbauer and Raman spectroscopies. Geochim Cosmochim Acta 61:1107-1111.

Urrutia MM, Roden EE, Fredrickson JK, Zachara JM. 1998. Microbial and surface chemistry controls on reduction of synthetic $\mathrm{Fe}$ (III) oxide minerals by the dissimilatory iron-reducing bacterium Shewanella alga. Geomicrobiol J 15:269-291.

Vins J, Subrt J, Zapletal V, Hanousek F. 1987. Preparation and properties of green rust type substances. Collection Czechoslovok Chem Commun 52:93-102.

Wang HD, White GN, Turner FT, Dixon JB. 1993. Ferrihydrite, lepidocrocite, and goethite in coatings from East Texas vertic soils. Soil Sci Soc Am J 57:1381-1386.

Whittmore DO, Langmuir D. 1975. The solubility of ferric oxyhydroxide s in natural waters. Groundwater 13:360-365.

Zachara JM, Fredrickson JK, Li S-M, Kennedy DW, Smith SC, Gassman PL. 1998. Bacterial reduction of crystalline $\mathrm{Fe}(\mathrm{III})$ oxides in single-phase suspensions and subsurface materials. Am Mineral 83:1426-1443.

Zachara JM, Fredrickson JK, Smith SC, Gassman PL. 2001. Solubilization of Fe(III) oxide-bound trace metals by a dissimilatory Fe(III) reducing bacterium. Geochim Cosmochim Acta 65:75-63. 